\title{
Aggregation-prone c9FTD/ALS poly(GA) RAN-translated proteins cause neurotoxicity by inducing ER stress
}

\author{
Yong-Jie Zhang • Karen Jansen-West · Ya-Fei Xu • Tania F. Gendron · Kevin F. Bieniek • Wen-Lang Lin • \\ Hiroki Sasaguri · Thomas Caulfield · Jaime Hubbard • Lillian Daughrity · Jeannie Chew $\cdot$ Veronique V. Belzil • \\ Mercedes Prudencio - Jeannette N. Stankowski • Monica Castanedes-Casey • Ena Whitelaw $\cdot$ Peter E. A. Ash • \\ Michael DeTure $\cdot$ Rosa Rademakers $\cdot$ Kevin B. Boylan $\cdot$ Dennis W. Dickson $\cdot$ Leonard Petrucelli
}

Received: 23 March 2014 / Revised: 20 August 2014 / Accepted: 20 August 2014 / Published online: 31 August 2014

(C) The Author(s) 2014. This article is published with open access at Springerlink.com

\begin{abstract}
The occurrence of repeat-associated nonATG (RAN) translation, an atypical form of translation of expanded repeats that results in the synthesis of homopolymeric expansion proteins, is becoming more widely appreciated among microsatellite expansion disorders. Such disorders include amyotrophic lateral sclerosis and frontotemporal dementia caused by a hexanucleotide repeat expansion in the C9ORF72 gene (c9FTD/ALS). We and others have recently shown that this bidirectionally transcribed repeat is RAN translated, and the "c9RAN proteins" thusly produced form neuronal inclusions throughout the central nervous system of c9FTD/ALS patients. Nonetheless, the potential contribution of c9RAN proteins to disease pathogenesis remains poorly understood. In the
\end{abstract}

Electronic supplementary material The online version of this article (doi:10.1007/s00401-014-1336-5) contains supplementary material, which is available to authorized users.

Y.-J. Zhang · K. Jansen-West · Y.-F. Xu · T. F. Gendron •

K. F. Bieniek · W.-L. Lin · H. Sasaguri · T. Caulfield ·

J. Hubbard · L. Daughrity · J. Chew · V. V. Belzil · M. Prudencio .

J. N. Stankowski · M. Castanedes-Casey $\cdot$ E. Whitelaw ·

M. DeTure · R. Rademakers · D. W. Dickson · L. Petrucelli $(\bowtie)$

Department of Neuroscience, Mayo Clinic Florida, Jacksonville,

FL 32224, USA

e-mail: petrucelli.leonard@ mayo.edu

K. F. Bieniek · J. Chew

Mayo Graduate School, Mayo Clinic College of Medicine,

Rochester, MN 55905, USA

P. E. A. Ash

Department of Pharmacology, Boston University School

of Medicine, Boston, MA 02118, USA

K. B. Boylan

Department of Neurology, Mayo Clinic Florida, Jacksonville,

FL 32224, USA present study, we demonstrate that poly(GA) c9RAN proteins are neurotoxic and may be implicated in the neurodegenerative processes of c9FTD/ALS. Specifically, we show that expression of poly(GA) proteins in cultured cells and primary neurons leads to the formation of soluble and insoluble high molecular weight species, as well as inclusions composed of filaments similar to those observed in c9FTD/ALS brain tissues. The expression of poly(GA) proteins is accompanied by caspase- 3 activation, impaired neurite outgrowth, inhibition of proteasome activity, and evidence of endoplasmic reticulum (ER) stress. Of importance, ER stress inhibitors, salubrinal and TUDCA, provide protection against poly(GA)-induced toxicity. Taken together, our data provide compelling evidence towards establishing RAN translation as a pathogenic mechanism of c9FTD/ALS, and suggest that targeting the ER using small molecules may be a promising therapeutic approach for these devastating diseases.

Keywords Amyotrophic lateral sclerosis - C9ORF72 . Expanded repeat $\cdot$ Frontotemporal dementia $\cdot$ Repeatassociated non-ATG translation · Poly(GA) proteins . Proteasome activity $\cdot$ ER stress

\section{Introduction}

Frontotemporal dementia (FTD) and amyotrophic lateral sclerosis (ALS) are devastating neurodegenerative disorders. Despite the fact that FTD presents with changes in behavior, personality and language and ALS is a motor neuron disease which leads to progressive paralysis, there is genetic, neuropathological and clinical overlap between them. Not only do FTD and ALS frequently occur in the same family, many ALS patients develop 
FTD-like cognitive and behavioral impairments [22, 39, 54], and as many as half of FTD patients develop motor neuron dysfunction [39]. Neuropathologically, neuronal and glial inclusions of TDP-43 are found in most ALS cases, as well as in the most common pathological subtype of FTD [frontotemporal lobar degeneration with TDP-43 pathology (FTLD-TDP)]. Because of this overlap, ALS and FTLD-TDP are considered part of a disease spectrum. This concept was recently reinforced with the discovery that a $\mathrm{G}_{4} \mathrm{C}_{2} \cdot \mathrm{G}_{2} \mathrm{C}_{4}$ repeat expansion in a non-coding region of the C9ORF72 gene is the most common genetic cause of ALS and FTLD-TDP [14, 41, 58].

How the repeat expansion in C9ORF72 causes "c9FTD/ALS" is not yet definitively known, but many advances have been made since the discovery of this mutation in 2011 (see [21] for review). Potential mechanisms include loss of C9ORF72 function due to epigenetic changes resulting in decreased C9ORF72 mRNA expression [5, 73]. In addition, repeat-containing RNAs bidirectionally transcribed from the expanded repeat are thought to contribute to disease pathogenesis. The binding of these transcripts by various RNA-binding proteins (RBPs) may impair the ability of these RBPs to interact with their respective RNA targets. Because the repeat-containing transcripts form nuclear RNA foci, RBPs that bind these transcripts may be sequestered therein, also resulting in their loss of function. Furthermore, we and others have shown that transcripts of expanded $\mathrm{G}_{4} \mathrm{C}_{2}$ and $\mathrm{G}_{2} \mathrm{C}_{4}$ repeats undergo repeat-associated non-ATG (RAN) translation [3, $20,43,44,78]$, an unconventional mode of translation that occurs in the absence of an initiating ATG and in all possible reading frames, first described by Ranum and colleagues [77]. RAN translation of expanded $\mathrm{G}_{4} \mathrm{C}_{2}$ and $\mathrm{G}_{2} \mathrm{C}_{4}$ repeats leads to the synthesis of 6 "c9RAN proteins" of repeating dipeptides: poly $(\mathrm{GA})$ and poly(GR) from sense $\mathrm{G}_{4} \mathrm{C}_{2}$ repeats, poly $(\mathrm{PR})$ and poly $(\mathrm{PA})$ from antisense $\mathrm{G}_{2} \mathrm{C}_{4}$ repeats, and poly $(\mathrm{GP})$ proteins from both sense and antisense transcripts.

Neuronal inclusions of c9RAN proteins are now considered a hallmark of c9FTD/ALS. While this implicates RAN translation as a mechanism of disease, confirmatory data are lacking. The Ranum group has shown that poly $(\mathrm{PR})$ and poly $(\mathrm{GP})$ proteins induce cellular toxicity in cultured cells independently of the accumulation of RNA foci [78], suggesting that c9RAN protein expression may indeed be detrimental. However, given that inclusions of poly $(\mathrm{GP})$ proteins are present in some, but not all, affected regions of the central nervous system (CNS) in c9FTD/ALS [3, 20], and a recent study showing that poly(GA) pathology, unlike TDP-43 pathology, does not correlate with the degree of neurodegeneration in c9FTD/ALS [40], put into question the contribution of
c9RAN proteins to disease pathogenesis. Conversely, the discovery of a c9FTD kindred with early intellectual disability and extensive poly(GA) inclusions but little, if any, TDP-43 pathology [56], provides compelling evidence that c9RAN proteins, or at least poly(GA) proteins, are harmful. Like poly(GP) inclusions, inclusions of poly(GA) appear to be abundant in c9FTD/ALS [37, 40, 43, 44, 56], perhaps because of the hydrophobic nature of the protein. Using various models, the present study thus sought to evaluate the neurotoxic potential of poly $(\mathrm{GA})$ protein expression and aggregation, as well as the mechanism(s) driving this toxicity.

\section{Materials and methods}

\section{Generation of plasmids}

To generate expression vectors for GFP- $(\mathrm{GA})_{50}$, GFP$(\mathrm{GP})_{47}$, GFP-(GR) $)_{50}$, GFP-(PR $)_{50}$ or GFP-(PA) $)_{50}$, gene fragments containing individual dipeptide repeats (Table 1) were synthesized by GeneArt and ligated to the HindIII and BamHI restriction sites of a pEGFP-C1 vector (Clontech Laboratories) in frame with the EGFP coding sequence. To generate the AAV1-GFP- $(\mathrm{GA})_{50}$ expression vector, the EGFP coding sequence with restriction sites identical to those in pEGFP-C1 and containing a stop codon in each frame downstream of the multiple cloning site was cloned into the AAV expression vector pAM/CBA-pl-WPRE-BGH ("pAAV"). Gene fragments from the gene synthesis were cloned into the HindIII and BamHI restriction sites of the pAAV EGFP fusion vector in frame with the EGFP coding sequence. To generate the GST-(GA) $)_{50}$ vector, PCR was performed to synthesize cDNA of a $(\mathrm{GA})_{50}$ fragment, which was then inserted into a pGEX-6P-1 vector (GE Healthcare) using BamHI and XhoI cloning sites. To generate the ATG- $(\mathrm{GA})_{50}$-V5 vector, cDNA of the $(\mathrm{GA})_{50}$ fragment with an ATG start codon was inserted into a pcDNA6-V5-His vector (Life Technologies) using HindIII and XhoI cloning sites. To generate the GFP-c $9(\mathrm{GA})_{50}$ expression vector, a gene fragment containing 50 pathological $\mathrm{G}_{4} \mathrm{C}_{2}$ repeats was produced as previously described [33], and then ligated to EcoRV restriction sites of a pcDNA6-V5-His vector (Life Technologies). The GFP sequence was inserted upstream of $\left(\mathrm{G}_{4} \mathrm{C}_{2}\right)_{50}$ using HindIII and EcoRI cloning sites to drive protein expression in the GA reading frame. To generate pAG3-6 $\times$ stops- $( \pm)$ ATG- $(\mathrm{GA})_{50}-3 \mathrm{~T}$ vectors, cDNA of the $(\mathrm{GA})_{50}$ fragment with or without an ATG start codon was inserted in a pAG3-6 $\times$ stops-3T vector between the 6 stop codons and the 3 tags (Online Resource 4a). The sequence of all plasmids was verified by sequence analysis. 
Table 1 Synthetic cDNA sequences used for expression vectors

\begin{abstract}
Synthetic (GA) ${ }_{50}$ sequence (GGXGCX)
GGTGCTGGAGCAGGAGCGGGAGCCGGCGCAGGAGCAGGTGCTGGCGCCGGAGC CGGAGCTGGAGCTGGAGCCGGCGCAGGCGCAGGAGCTGGAGCTGGAGCAGGAG CCGGTGCAGGGGCTGGCGCAGGTGCTGGTGCTGGAGCCGGAGCAGGAGCAGGA GCAGGTGCGGGAGCCGGAGCTGGAGCTGGAGCCGGCGCTGGTGCGGGTGCTGG CGCAGGCGCAGGCGCTGGCGCTGGAGCAGGAGCTGGAGCAGGTGCAGGAGCAG GCGCAGGAGCCGGAGCAGGTGCAGGTGCAGGCGCT
\end{abstract}

\begin{abstract}
Synthetic (GP) 47 sequence (GGXCCX)
GGACCTGGACCTGGCCCTGGGCCAGGACCTGGACCTGGACCAGGACCTGGACCT GGTCCTGGCCCAGGACCTGGACCAGGACCGGGTCCAGGACCTGGCCCAGGGCC CGGGCCCGGTCCAGGACCAGGTCCTGGACCGGGCCCTGGACCGGGACCTGGCC CCGGACCCGGACCAGGACCGGGCCCAGGACCAGGACCTGGCCCTGGACCTGGA CCTGGTCCGGGTCCTGGTCCTGGACCAGGGCCAGGTCCTGGTCCSGGTCCAGGA CCTGGCCCAGGACCAT
\end{abstract}

\begin{abstract}
Synthetic (GR) ${ }_{50}$ sequence (GGXCGX)
GGCCGCGGCCGTGGTCGCGGTCGTGGACGTGGCCGTGGCCGTGGCCGAGGTCG CGGTCGGGGACGTGGCCGTGGTCGTGGCCGAGGTCGAGGTCGCGGACGTGGAC GTGGTCGAGGTCGGGGACGTGGACGAGGCCGTGGTCGTGGCCGAGGTCGCGGA CGTGGGCGAGGTCGCGGTCGAGGCCGGGGACGTGGCCGTGGTCGTGGACGGGG ACGGGGTCGGGGACGCGGTCGAGGCCGTGGACGTGGACGGGGTCGAGGACGTG GACGTGGTCGTGGACGTGGCCGTGGACGTGGACGG
\end{abstract}

\begin{abstract}
Synthetic (PR) $)_{50}$ sequence (CGXCCX)
CGTCCACGTCCACGGCCACGTCCACGACCACGTCCACGTCCTCGACCCCGTCCAC GTCCACGGCCTCGACCGCGTCCCCGACCCCGTCCCCGTCCACGACCACGGCCAC GTCCCCGGCCTCGACCGCGACCTCGCCCACGTCCGCGACCTCGGCCACGACCAC GGCCTCGTCCACGTCCCCGACCTCGACCACGTCCACGTCCGCGACCTCGACCTC GGCCACGACCACGGCCACGTCCCCGACCGCGACCTCGGCCACGGCCACGGCCA CGTCCACGACCGCGACCACGGCCGCGGCCC
\end{abstract}

\begin{tabular}{l} 
Synthetic (PA) $)_{50}$ sequence (CCXGCX) \\
\hline CCAGCGCCTGCACCTGCACCTGCTCCGGCTCCTGCGCCTGCTCCTGCACCTGCTC \\
CAGCTCCTGCTCCAGCGCCAGCGCCTGCGCCTGCGCCAGCACCCGCACCAGCGC \\
CGGCTCCAGCTCCAGCTCCGGCTCCCGCACCTGCTCCTGCTCCTGCTCCGGCTCC \\
AGCACCAGCACCTGCGCCAGCCCCTGCACCGGCTCCTGCTCCAGCTCCAGCTCCT \\
GCGCCTGCGCCGGCTCCAGCTCCAGCTCCGGCTCCGGCGCCAGCACCTGCTCCT \\
GCGCCGGCTCCCGCTCCTGCTCCAGCACCC
\end{tabular}

The target sequence of the FISH probe for the synthetic $(\mathrm{GA})_{50}$ sequence is highlighted in yellow the antigen to produce rabbit polyclonal antibodies. Preimmune serum from rabbits was tested against brain tissue from c9FTD/ALS cases by immunohistochemistry and confirmed negative. Antiserum was used directly for Western blot and immunohistochemistry studies.

Immunohistochemistry and semi-quantitative analysis of poly(GA) inclusions in c9FTD/ALS

Neuropathological assessment was performed on 10 cases with the expanded C9ORF72 hexanucleotide repeat. These cases were neuropathologically diagnosed as frontotemporal lobar degeneration (FTLD; $N=4$ ), amyotrophic lateral sclerosis (ALS; $N=4$ ), or both (FTLD-MND; $N=2$ ). Four regions of formalin-fixed paraffin-embedded tissue from the left hemi-brain were selected: the midfrontal gyrus of the frontal lobe, the posterior hippocampus at the level of the lateral geniculate nucleus (including occipitotemporal gyrus), the thalamus at the level of the subthalamic nucleus, and the cerebellum

centrated. Recombinant GST-(GA) $)_{50}$ protein was used as 
Table 2 Poly $(\mathrm{GA})$ neuropathology in c9FTD/ALS cases

\pm Sparse, + mild, ++ moderate, +++ severe, $* *$ cells autolyzed, $C A 3 / 2$ hippocampus proper, $D F$ dentate fascia, $G C L$ granule cell layer, $M L$ molecular layer, Path Dx neuropathologic diagnosis

\begin{tabular}{|c|c|c|c|c|c|c|c|c|}
\hline \multirow[t]{2}{*}{ Path Dx } & \multirow[t]{2}{*}{ Case \# } & \multicolumn{2}{|c|}{ Hippocampus } & \multirow[t]{2}{*}{ Temporal cortex } & \multirow[t]{2}{*}{ Frontal cortex } & \multirow[t]{2}{*}{ Thalamus } & \multicolumn{2}{|c|}{ Cerebellum } \\
\hline & & DF & $\mathrm{CA} 3 / 2$ & & & & ML & GCL \\
\hline FTLD & 1 & ++ & ++ & ++ & ++ & ++ & ++ & +++ \\
\hline FTLD & 2 & + & + & ++ & ++ & \pm & + & ++ \\
\hline FTLD & 3 & + & + & + & + & ++ & ++ & + \\
\hline FTLD & 4 & ++ & ++ & ++ & + & ++ & + & +++ \\
\hline FTLD-MND & 5 & ++ & ++ & +++ & +++ & + & ++ & +++ \\
\hline FTLD-MND & 6 & + & + & + & ++ & ++ & \pm & ++ \\
\hline ALS & 7 & ++ & + & ++ & ++ & ++ & + & $* *$ \\
\hline ALS & 8 & +++ & + & ++ & ++ & + & ++ & +++ \\
\hline ALS & 9 & ++ & ++ & ++ & ++ & \pm & ++ & +++ \\
\hline ALS & 10 & ++ & ++ & ++ & ++ & + & ++ & ++ \\
\hline
\end{tabular}

with the dentate nucleus. Tissue was cut into $6-\mu \mathrm{m}$-thick sections, mounted on glass slides, and dried overnight. Slides were subsequently deparaffinized and immunohistochemistry was performed using 30 min of antigen retrieval (steam), Dako EnVision+ reagents and Autostainer (DAKO), and the anti-poly(GA) rabbit polyclonal antibody $(1: 50,000)$. Following immunohistochemistry, all slides were counterstained with Lerner's hematoxylin, dehydrated, and coverslipped. Slides were analyzed semiquantitatively (Table 2) on an Olympus BX40 microscope (Olympus America). Neuropathologic burden was graded on a 4-point scale: sparse $( \pm)$, mild $(+)$, moderate $(++)$, and severe $(+++)$. In densely neuronal-populated regions, such as the internal granule cell layer of the cerebellum and the dentate fascia of the hippocampus, the pathologic grade was validated using averaged counts in $40 \times$ and $20 \times$ magnification microscopic fields, respectively. Slides were imaged using a Zeiss AxioImager Z1 microscope (Carl Zeiss Microscopy).

Electron microscopy (EM) and immuno-electron microscopy (immuno-EM)

To examine the filamentous structure of recombinant GST-(GA) 50 proteins, recombinant GST or GST-(GA) $)_{50}$ proteins were diluted to $1 \mu \mathrm{g} / \mu \mathrm{l}$ in $20 \mathrm{mM}$ Tris $-\mathrm{HCl}$, pH 7.5, $50 \mathrm{mM} \mathrm{KCl}, 10 \mathrm{mM} \mathrm{MgCl}_{2}$ in a final volume of $30 \mu \mathrm{l}$. The samples were incubated at $30^{\circ} \mathrm{C}$ for $6 \mathrm{~h}$, and then diluted to $0.1 \mu \mathrm{g} / \mu \mathrm{l}$ by reaction buffer and loaded onto grids for regular EM analysis. For immuno-EM analysis, mouse monoclonal anti-GST antibody (1:20, Thermo Scientific) was used as primary antibody, and goat anti-mouse $\operatorname{IgG}$ conjugated with $6 \mathrm{~nm}$ colloidal gold particles (1:20, Jackson ImmunoResearch Laboratories) was used as the secondary antibody. To examine the filamentous structure of poly $(\mathrm{GA})$ proteins in c9FTD/ALS patients, small pieces $(1.5 \times 1.5 \times 1 \mathrm{~mm})$ of cerebellar folia or hippocampus from formalin-fixed brains were dissected and processed for routine electron microscopy (EM) or post-embedding immunogold EM as previously described [34]. Rabbit polyclonal antipoly(GA) antibody (1:50) was used as a primary antibody and goat anti-rabbit IgG conjugated with $18 \mathrm{~nm}$ colloidal gold particles (1:20, Jackson ImmunoResearch Laboratories) was used as the secondary antibody. Thin sections stained with uranyl acetate and lead citrate were examined with a Philips 208S electron microscope (FEI) fitted with a Gatan 831 Orius CCD camera (Gatan). Digital images were processed with Adobe Photoshop CS5 software.

Preparation of urea fractions and dot blot analysis of frozen cerebellar tissue

The urea fraction of human tissues was prepared as previously described [46, 75]. In brief, $\sim 100 \mathrm{mg}$ frozen postmortem cerebellar tissue from carriers and non-carriers of the C9ORF72 repeat expansion was subjected to a sequential extraction protocol using low-salt buffer, high salt-Triton X-100 buffer, myelin floatation buffer, and sarkosyl buffer. Sarkosyl-insoluble material was finally extracted in urea buffer and saved as the urea fraction. For dot blots, urea fractions ( $2 \mu \mathrm{l}$ per sample) were dotted directly onto nitrocellulose membrane. After incubation at $37{ }^{\circ} \mathrm{C}$ for $30 \mathrm{~min}$, the membrane was blocked with $5 \%$ nonfat dry milk in Tris-buffered saline containing $0.1 \%$ Triton X-100 (TBST) for $1 \mathrm{~h}$, then incubated with rabbit polyclonal anti-poly(GA) antibody $(1: 1000)$ overnight at $4{ }^{\circ} \mathrm{C}$. The membrane was washed in TBST, and then incubated with donkey anti-rabbit IgG conjugated to horseradish peroxidase (1:5000, Jackson ImmunoResearch Laboratories) for $1 \mathrm{~h}$. Protein expression was visualized by enhanced chemiluminescence treatment and exposure to a film. 
Preparation of cell lysates

HEK293T cells grown in 6-well plates were transfected for $48 \mathrm{~h}$ with $1 \mu \mathrm{g}$ of an expression vector [GFP or GFP$(\mathrm{GA})_{50}$ ] or $5 \mu \mathrm{g}$ of an expression vector [ATG-(GA) $)_{50}-\mathrm{V} 5$, ATG-(GA) ${ }_{100}-\mathrm{V} 5$, ATG-(GA) $50^{-3 \mathrm{~T}}$ or $\left.(\mathrm{GA})_{50}-3 \mathrm{~T}\right]$ using Lipofectamine 2000 (Life Technologies). To prepare Triton X-100 soluble and insoluble fractions, cell pellets expressing GFP or GFP-(GA) $)_{50}$ were lysed in Co-IP buffer (50 mM Tris-HCl, pH 7.4, $300 \mathrm{mM} \mathrm{NaCl}, 1 \%$ Triton $\mathrm{X}-100,5 \mathrm{mM}$ EDTA) containing PMSF as well as protease and phosphatase inhibitors. Lysates were sonicated on ice, and then centrifuged at $16,000 \mathrm{~g}$ for $20 \mathrm{~min}$. Supernatants were saved as Triton X-100-soluble fractions. The insoluble pellets were dissolved in Co-IP buffer plus $2 \%$ SDS, PMSF, and both a protease and phosphatase inhibitor mixture. After sonication, lysates were centrifuged at $16,000 \mathrm{~g}$ for $20 \mathrm{~min}$, and these supernatants were saved as Triton X-100-insoluble fractions. To prepare total cell lysates, pellets from cells transfected with ATG-(GA) ${ }_{50^{-}}$ V5, ATG-(GA) $100^{-V} 5$, ATG-(GA) $50^{-3 T}$ or $(\mathrm{GA})_{50}-3 \mathrm{~T}$ constructs were lysed in Co-IP buffer plus $2 \%$ SDS, PMSF, and both protease and phosphatase inhibitor mixture. After sonication, lysates were centrifuged at $16,000 \mathrm{~g}$ for $20 \mathrm{~min}$. The protein concentration of supernatants was determined by BCA assay (Thermo Scientific) prior to Western blot analysis.

\section{Fluorescence in situ hybridization (FISH)}

To examine RNA foci, cells were subjected to FISH. In brief, HEK293T cells grown on glass coverslips in 24-well plates were transfected with $0.5 \mu \mathrm{g}$ GFP-(GA) $)_{50}$ or GFP-c $9(\mathrm{GA})_{50}$ expression vectors made, respectively, with a synthetic sequence $\left[(\mathrm{GGXGCX})_{50}\right.$; GFP- $\left.(\mathrm{GA})_{50}\right]$ or a pathological sequence $\left[(\mathrm{GGGGCC})_{50}\right.$; GFP-c $\left.9(\mathrm{GA})_{50}\right]$. After $24 \mathrm{~h}$, cells were fixed in $4 \%$ paraformaldehyde for 20 min, permeabilized in DEPC-treated PBS- $0.2 \%$ Triton X-100 for 10 min, and washed 3 times with DEPC-treated PBS. Cells were hybridized with denatured $\mathrm{Cy} 3$-conjugated probe (5'-Cy3/GGCUCCAGCACCAGCACCUGC GCC-3', $2 \mathrm{ng} / \mu \mathrm{l})$ for the synthetic sequence, or $\left(5^{\prime}-\mathrm{Cy} 3\right.$ /GGCCCCGGCCCCGGCCCCGGCCCC-3', 2 ng/ $\mu \mathrm{l}$ ) for the pathological sequence, overnight at $37^{\circ} \mathrm{C}$. The composition of the hybridization buffer was $50 \%$ formamide, $10 \%$ dextran sulfate, $0.1 \mathrm{mg} / \mathrm{ml}$ yeast tRNA, $2 \times \mathrm{SSC}$, $50 \mathrm{mM}$ sodium phosphate. Cells were then washed once with $50 \%$ formamide $/ 1 \times \mathrm{SSC}$ for $30 \mathrm{~min}$ at $37^{\circ} \mathrm{C}$, and twice with DEPC-PBS at room temperature for $5 \mathrm{~min}$. Then, the cells were counterstained with Hoechst 33258 (1 $\mu \mathrm{g} / \mathrm{ml}$, Life Technologies). Immunostained cells were visualized using a Zeiss LSM 510 META confocal microscope.
Cell culture, immunofluorescence staining

and quantification of activated caspase-3-positive cells

HEK293T cells grown on glass coverslips in 24-well plates were transfected with $0.5 \mu \mathrm{g}$ of an expression vector [GFP, GFP-(GA) $)_{5}$, GFP-(GA) $)_{50}$, ATG-(GA) ${ }_{50}-\mathrm{V} 5$, ATG-(GA) ${ }_{100^{-}}$ V5, ATG-(GA) $)_{50}-3 \mathrm{~T}$ or $\left.(\mathrm{GA})_{50}-3 \mathrm{~T}\right]$ using Lipofectamine 2000 (Life Technologies). After 48 h, media was collected for analysis using an LDH assay (Promega) to assess cell toxicity. In addition, cells were fixed with $4 \%$ paraformaldehyde in PBS for $15 \mathrm{~min}$, and then permeabilized with PBS- $0.5 \%$ Triton X-100 for $10 \mathrm{~min}$. To examine caspase-3 activation, cells were blocked with $5 \%$ nonfat milk for $1 \mathrm{~h}$ at room temperature, then incubated overnight at $4{ }^{\circ} \mathrm{C}$ with rabbit polyclonal anti-activated caspase-3 antibody (9661, 1:250, Cell signaling) and mouse monoclonal anti-HA antibody (clone 3F10, 1:1000, Roche; used for cells expressing HA-tagged proteins) or mouse monoclonal anti-V5 antibody (R960-25, 1:2000, Life Technologies; used for cells expressing V5-tagged proteins). To determine whether poly(GA) inclusions are ubiquitin- and p62-positive, cells expressing ATG-(GA) $100^{-V 5}$ were incubated with rabbit polyclonal anti-V5 antibody (V8137, 1:2000, Sigma) and mouse monoclonal anti-ubiquitin (clone Ubi-1, 1:100, EMD Millipore) or mouse monoclonal anti-p62 (610833, 1:100, BD Biosciences) antibodies. To examine the ERGolgi distribution of GFP-(GA) 50 inclusions, cells were subjected to immunofluorescence staining using rabbit polyclonal anti-giantin antibody (ab24586, 1:250, Abcam) or mouse monoclonal anti-KDEL antibody (10C3, 1:500, StressGen). After washing, cells were incubated with the corresponding Alexa Fluor 488 donkey anti-mouse and Alexa 568-conjugated donkey anti-rabbit secondary antibody (1:500, Molecular Probes) at room temperature for $2 \mathrm{~h}$. Hoechst $33258(1 \mu \mathrm{g} / \mathrm{ml}$, Life Technologies) was used to stain cellular nuclei. Images were obtained on a Zeiss LSM 510 META confocal microscope. To quantify the number of cells positive for activated caspase- 3 staining, coverslips mounted on slides were scanned by Aperio ScanScope. Sixteen fields were randomly selected under $20 \times$ magnification. For each field, the number of activated caspase-3-positive cells and the number of GFP-positive cells were counted in a blinded fashion using MetaMorph software. These counts were used to calculate the average percentage of activated caspase-3-positive cells in cells expressing GFP, GFP-(GA) $)_{5}$ or GFP-(GA) $)_{50}$.

Primary neuronal culture preparation, quantification of neurite outgrowth and immunofluorescence staining

Primary neuronal cultures were prepared as previously described [76]. In brief, the cortex from embryonic day 18 (E18) mice was dissected and digested. Following 
centrifugation to collect the cell pellet, cells were resuspended in Neurobasal A (Life Technologies) supplemented with B27, GMAX, gentamicin and bFGF (Life Technologies). Neurons were seeded at a density of $9 \times 10^{3}$ cells/ well in 96-well plates, $2 \times 10^{4}$ cells/coverslip in 24 -well plates, or $7 \times 10^{5}$ cells/well in 6-well plates. At day in vitro 4, neurons were transduced to express GFP, GFP-(GA) $)_{50}$, or ATG-(GA) ${ }_{100}-\mathrm{V} 5$. The following numbers of rAAV1 genome particles were used for 96-, 24- and 6-well plates, respectively: $1 \times 10^{9}, 1.2 \times 10^{9}$, and $1 \times 10^{10}$. Quantification of neurite outgrowth was performed as previously described [19, 76], using neurons in 96-well plates immunostained 5 days post-transduction with mouse monoclonal anti-MAP2 antibody (M9942, 1:1000, Sigma) and rabbit polyclonal anti-V5 antibody (V8137, 1:2000, Sigma) (used for cells expressing V5-tagged proteins). The average total neurite length per neuron was calculated for all groups using counts obtained in a blinded fashion. Caspase-3 activation was evaluated using neurons on glass coverslips in 24-well plates. Seven days post-transduction, neurons were fixed and immunostained using a rabbit polyclonal anti-activated caspase-3 antibody (9661, 1:250, Cell signaling) and/or mouse monoclonal anti-V5 antibody (R960-25, 1:2000, Life Technologies). Western blot analysis and LDH studies were conducted using neurons grown in 6-well plates. Seven days post-transduction, media was collected for the LDH assay, and cells were lysed in Co-IP buffer with $2 \%$ SDS, PMSF, as well as protease and phosphatase inhibitors. Lysates were sonicated and centrifuged at 16,000 $\mathrm{g}$ for $20 \mathrm{~min}$. Supernatants were saved and the protein concentration was determined by BCA assay. Samples were analyzed by Western blot. Some cultures were exposed to different treatments. Non-transduced neurons were treated with tunicamycin $(10 \mu \mathrm{g} / \mu \mathrm{l}$, Sigma) or MG-132 (10 $\mu \mathrm{M}$, EMD4Biosciences) at day in vitro 6, then harvested the next day. Neurons expressing GFP-(GA) 50 were treated with a fresh preparation of TUDCA $(0.25$ or $0.5 \mathrm{mM}$, EMD4Biosciences) 1 day after transduction or salubrinal ( 2.5 or $5.0 \mu \mathrm{M}$, Sigma) 3 days after transduction. Seven days after transduction, TUDCA- or salubrinaltreated neurons were harvested for analysis.

\section{Proteasome activity assay}

Proteasome activity assays were performed as previously described [61]. In brief, pellets of neurons subjected to different treatments were lysed in $350 \mu 1$ of assay buffer (10 mM Tris- $\mathrm{HCl}, 0.5 \mathrm{mM}$ DDT, $5 \mathrm{mM}$ ATP, $0.035 \%$ SDS, $5 \mathrm{mM} \mathrm{MgCl}_{2}$, pH 7.8). After homogenization, cell lysates were centrifuged at $1,000 \mathrm{~g}$ for $10 \mathrm{~min}$. The supernatants were collected and the protein concentration was determined by Bradford assay (Thermo Scientific). Then, the proteasome substrate Suc-Leu-Leu-Val-Tyr-AMC was added to $300 \mu \mathrm{l}$ of lysate at a final concentration of $40 \mu \mathrm{M}$. The reaction was started by incubating samples at $37^{\circ} \mathrm{C}$ for $30 \mathrm{~min}$, and then terminated by adding $75 \mu 1 \mathrm{H}_{2} \mathrm{O}$ and $11.25 \mu 1$ ethanol to quench the substrate. After centrifugation at $1,000 \mathrm{~g}$ for $3 \mathrm{~min}, 100 \mu \mathrm{l}$ of each sample was added into a black 96-well plate in triplicate. Fluorescence was measured at $360 \mathrm{~nm}$ excitation and $465 \mathrm{~nm}$ emission. Data was normalized to the GFP control group.

\section{Live cell imaging}

HEK293T cells grown in 96-well plates were transfected with $0.1 \mu \mathrm{g}$ of GFP-(GA) $)_{50}$ vector using Lipofectamine 2000 (Life Technologies). To monitor inclusion formation $12 \mathrm{~h}$ post-transduction, images of live cells were obtained every $5 \mathrm{~min}$ for $5 \mathrm{~h}$ using the BD pathway 855 . The resulting images were combined to create the video shown in the Online Resources section.

\section{Western blot analysis}

Western blot analysis was performed as previously described $[75,76]$. In brief, samples were heated in Laemmli's buffer, and equal amounts of protein were loaded into 10 -well $10 \%$ or 4-20\% Tris-glycine gels (Novex). After transfer, blots were blocked with $5 \%$ nonfat dry milk in TBST for $1 \mathrm{~h}$, then incubated with a rabbit polyclonal anti-GFP antibody (A-6455, 1:2000, Life Technologies), rabbit polyclonal anti-activated caspase-3 antibody (9661, 1:1000, Cell signaling), mouse monoclonal anti-V5 antibody (R960-25, 1:2000, Life Technologies), rabbit polyclonal anti-poly(GA) serum (1:4000), mouse monoclonal anti-GST antibody (MA4-004, 1:2000, Thermo Scientific), mouse monoclonal anti-HA antibody (clone 3F10, 1:1000, Roche), mouse monoclonal anti-Myc antibody (clone 9E10, 1:1000, Roche), mouse monoclonal anti-Flag antibody (F3165, 1:1000, Sigma), rabbit polyclonal anti-ubiquitin antibody (Z0458, 1:1000, Dako), mouse monoclonal anti-BIP antibody (610978, 1:1000, BD Biosciences), rabbit polyclonal anti-CHOP antibody (sc-575, 1:200, Santa Cruz Biotechnology), rabbit polyclonal anti-phosphoPERK (sc-32577, 1:500, Santa Cruz Biotechnology), rabbit polyclonal anti-PERK (sc-13073, 1:1000, Santa Cruz Biotechnology), rabbit polyclonal anti-ATF6 (sc-22799, 1:1000, Santa Cruz Biotechnology), rabbit polyclonal antiphospho-eIF $2 \alpha$ (9721, 1:500, Cell signaling) or mouse monoclonal GAPDH antibody (H86504 M, 1:10000, Meridian Life Science) overnight at $4^{\circ} \mathrm{C}$. Membranes were washed in TBST and incubated with donkey antirabbit or anti-mouse IgG conjugated to horseradish peroxidase (1:5000; Jackson ImmunoResearch) for $1 \mathrm{~h}$. Protein expression was visualized by enhanced chemiluminescence treatment and exposure to film. 
Table 3 ALS cases with or without the C9ORF72 repeat expansion used for qPCR analysis of ER stress markers

\begin{tabular}{|c|c|c|c|c|c|}
\hline Path Dx & Case \# (continued from Table 2) & $C 9 O R F 72$ repeat expansion & Gender & Age of onset & Age of death \\
\hline c9ALS & 7 & Y & M & 52 & 58 \\
\hline c9ALS & 9 & $\mathrm{Y}$ & $\mathrm{F}$ & $\mathrm{n} / \mathrm{a}$ & 49 \\
\hline c9ALS & 10 & $\mathrm{Y}$ & $\mathrm{F}$ & $\mathrm{n} / \mathrm{a}$ & 41 \\
\hline c9ALS & 11 & $\mathrm{Y}$ & $\mathrm{F}$ & 61 & 64 \\
\hline c9ALS & 12 & Y & M & 56 & 58 \\
\hline c9ALS & 13 & $\mathrm{Y}$ & M & 49 & 53 \\
\hline c9ALS & 14 & $\mathrm{Y}$ & $\mathrm{F}$ & $\mathrm{n} / \mathrm{a}$ & 50 \\
\hline c9ALS & 15 & $\mathrm{Y}$ & $\mathrm{F}$ & $\mathrm{n} / \mathrm{a}$ & 50 \\
\hline ALS & 16 & $\mathrm{~N}$ & M & 45 & 50 \\
\hline ALS & 17 & $\mathrm{~N}$ & M & 53 & 58 \\
\hline ALS & 18 & $\mathrm{~N}$ & $\mathrm{~F}$ & $\mathrm{n} / \mathrm{a}$ & 53 \\
\hline ALS & 19 & $\mathrm{~N}$ & M & $\mathrm{n} / \mathrm{a}$ & 47 \\
\hline ALS & 20 & $\mathrm{~N}$ & $\mathrm{~F}$ & $\mathrm{n} / \mathrm{a}$ & 60 \\
\hline ALS & 21 & $\mathrm{~N}$ & $\mathrm{~F}$ & $\mathrm{n} / \mathrm{a}$ & 65 \\
\hline ALS & 22 & $\mathrm{~N}$ & $\mathrm{~F}$ & $\mathrm{n} / \mathrm{a}$ & 69 \\
\hline ALS & 23 & $\mathrm{~N}$ & $\mathrm{~F}$ & $\mathrm{n} / \mathrm{a}$ & 70 \\
\hline ALS & 24 & $\mathrm{~N}$ & $\mathrm{~F}$ & $\mathrm{n} / \mathrm{a}$ & 72 \\
\hline ALS & 25 & $\mathrm{~N}$ & $\mathrm{~F}$ & $\mathrm{n} / \mathrm{a}$ & 79 \\
\hline ALS & 26 & $\mathrm{~N}$ & $\mathrm{~F}$ & $\mathrm{n} / \mathrm{a}$ & 80 \\
\hline
\end{tabular}

RNA extraction, semi-quantitative PCR and quantitative PCR (qRT-PCR)

Total RNA was extracted from HEK293T cells, neurons or frozen postmortem frontal cortex tissues using the RNAeasy Plus Mini Kit (QIAGEN) as per the manufacturer's instructions, combined with an in-column DNase I digestion step. RNA integrity was obtained using the Agilent 2100 Bioanalyzer (Agilent Technologies). cDNA was obtained after reverse-transcription polymerase chain reactions using 500-2000 ng of RNA with random primers and the High Capacity cDNA Transcription Kit (Applied Biosystems) as per the manufacturer's instructions. To examine XBP1 splicing in neurons, $2 \mu 1$ of cDNA was used in a $20 \mu \mathrm{l}$ reaction according to the manufacturer's protocol for a Taq PCR Core kit (Qiagen). The PCR primers for XBP1 and GAPDH were used as in previously described [28]. The amplification conditions consisted of an initial denaturation step at $95{ }^{\circ} \mathrm{C}$ for $5 \mathrm{~min} ; 10$ cycles of $94{ }^{\circ} \mathrm{C}$ for $20 \mathrm{~s}, 65-55{ }^{\circ} \mathrm{C}$ touchdown for $20 \mathrm{~s}$, and $72{ }^{\circ} \mathrm{C}$ for $30 \mathrm{~s}$; 35 cycles of $94{ }^{\circ} \mathrm{C}$ for $20 \mathrm{~s}, 58{ }^{\circ} \mathrm{C}$ for $20 \mathrm{~s}$, and $72{ }^{\circ} \mathrm{C}$ for $30 \mathrm{~s}$, and a final extension at $72{ }^{\circ} \mathrm{C}$ for $5 \mathrm{~min}$. The PCR products were run on $2 \%$ agarose gels for $35 \mathrm{~min}$ at $135 \mathrm{~V}$. The intensity of unspliced and spliced XBP1 bands was quantified by densitometric analysis using Fujifilm MultiGauge software, and then the percentage of unspliced or spliced XBP1 was calculated.
To quantify mRNA levels of GFP, GFP-(GA) $)_{5}$ and GFP$(\mathrm{GA})_{50}$ in HEK293T cells or neurons, quantitative PCR (qRT-PCR) was conducted in triplicate for all samples using SYBR green assay (Life Technologies) on an ABI Prism 7900HT Fast Real-Time PCR System (Applied Biosystems). The primers used were: GFP: 5'-GAAGCGCGATCACATGGT- $3^{\prime}$ and 5'-CCATGCCGAGAGTGATCC-3'; GAPDH: $\quad 5^{\prime}$-CATGGCCTTCCGTGTTCCTA- $3^{\prime}$ and 5'-CCTGCTTCACCACCTTCTTGAT-3'. The mRNA values of GFP, GFP-(GA) 5 and GFP-(GA) 50 were normalized to GAPDH values, an endogenous transcript control. To quantify ER stress markers in frontal cortex tissues from ALS patients with or without the C9ORF72 repeat expansion (Table 3), qRT-PCR was performed using TaqMan assays (Life Technologies) for ATF4 (Hs00909569_g1), CHOP (Hs00358796_g1), or BIP (Hs00946350_g1), or a SYBR green assay for RPLP0 (primers: 5'-TCTACAACCCTGAAGTGCTTGAT- $3^{\prime}$ and 5'-CAATCTGCAGACAGACACTGG- $3^{\prime}$ ). The mRNA values of ATF4, CHOP, and BIP were normalized to RPLP0 values, an endogenous transcript control. Since it has been reported that GAPDH expression is altered in neurodegenerative diseases [11], we evaluated several endogenous controls by qRT-PCR in the frontal cortex regions and RPLP0 was chosen because this transcript presented overall low $C_{t}$ values and lowest $C_{t}$ variation (unpublished data). In addition, RPLP0 has been used as a stable reference gene in previous studies $[1,16$, 31]. 


\section{Results}

Poly(GA) proteins form abundant inclusions in c9FTD/ALS

To investigate the contribution of poly(GA) inclusions to c9FTD/ALS pathogenesis, we generated a rabbit polyclonal antibody using recombinant GST-(GA) $)_{50}$ protein as the antigen. Analysis of recombinant GST-(GA) $)_{50}$, in comparison to GST alone, confirmed that it forms high molecular weight species (arrow, Online Resource 1a) and filamentous structures in vitro (Online Resource $1 \mathrm{~b}$ and $\mathrm{c}$ ), rendering it an ideal antigen for the production of antibodies to detect poly(GA) pathology. Indeed, the resulting antibodies, which specifically detect poly(GA) protein and no other c9RAN proteins (Online Resource 1d), stain inclusions throughout the CNS of c9FTD/ALS cases (Fig. 1a-f; Table 2) but not age-matched FTLD-TDP and ALS cases without the C9ORF72 repeat expansion (Online Resource 1e). Further confirming specificity of this novel polyclonal poly(GA) antibody, immunostaining c9FTD/ALS tissues with pre-immune serum was negative (Online Resource 1f). The distribution of anti-poly(GA) immunoreactive inclusions in c9FTD/ALS (Table 2) paralleled that of poly(GP) inclusions, which we previously reported to be enriched in the cerebellum, hippocampus, and neocortex [3]. Poly(GA) inclusions were predominantly neuronal cytoplasmic inclusions (NCI), but neuronal intranuclear inclusions (NIIs) (arrow in insert, Fig. 1a) were also observed. Electron microscopy (EM) studies of NCI in granule cells of the cerebellum (Fig. 1g) showed that the inclusions contain 15$17 \mathrm{~nm}$ filaments (arrow, Fig. 1h). Immuno-EM with antipoly(GA) antibody confirmed the localization of poly(GA) proteins to these filaments (arrow, Fig. 1i). Consistent with these findings, insoluble poly(GA) proteins were detected in urea fractions of c9FTD/ALS cerebellar tissue, but not in cerebellar tissue from FTLD and ALS cases with no expanded repeat, as assessed by dot blot (Fig. 1j).

Poly(GA) proteins form inclusions and are toxic in cultured cells

In investigating the potential contribution of poly(GA) proteins to neurodegeneration in c9FTD/ALS, we generated expression constructs for CMV-promoted, ATG-initiated translation of synthetic repeats encoding GFP-tagged (GA) or $(\mathrm{GA})_{50}$. For comparison purposes, we also produced vectors for the expression of all other c9RAN proteins [GFP$(\mathrm{GP})_{47}$, GFP-(GR) $)_{50}$, GFP-(PR) $)_{50}$ or GFP-(PA) $\left.)_{50}\right]$. Similar to the intracellular localization of GFP alone, GFP-(GP) 47 and GFP-(PA) $)_{50}$ were diffusely distributed throughout cells, whereas GFP-(GR) 50 and GFP-(PR) 50 accumulated into discrete nuclear structures (Online Resource 2). In contrast, GFP-(GA) $)_{50}$ formed many inclusions, the majority of which were cytoplasmic, although the occasional nuclear inclusion was observed (arrow, Fig. 2a). These results suggest that, among c9RAN proteins, poly $(\mathrm{GA})$ is especially aggregation prone. The propensity of poly(GA) proteins to aggregate, however, is dependent on repeat length given that GFP-(GA) 5 remained diffusely distributed in transfected cells (Fig. 2a). Poly(GA) aggregation also appears to be a relatively rapid process. Upon monitoring GFP-(GA) $)_{50}$ inclusion formation in living cells, it was observed that, within a span of only $5 \mathrm{~min}$, diffuse GFP$(\mathrm{GA})_{50}$ can quickly form a small aggregate, which then goes on to become a large inclusion within approximately 30 min (Fig. 2b, Online Resource 3). The aggregation of GFP-(GA) $)_{50}$ is not likely the result of a tag artifact since poly(GA) inclusions were also observed in cells expressing ATG-(GA) ${ }_{100}$-V5 (Fig. 2c). Of note, (GA) ${ }_{100}$-V5 inclusions were ubiquitin- and p62-positive (Fig. 2c), reminiscent of poly(GA) pathology in c9FTD/ALS [2, 44]. Likewise, similar to the filaments observed in c9FTD/ALS tissue, GFP$(\mathrm{GA})_{50}$ inclusions in cultured cells were composed of filamentous structures (arrow, Fig. 2d). Consistent with these findings, Western blot analysis of Triton X-100 soluble and insoluble transfected cell fractions revealed that, while GFP was detected as a monomer in the soluble fraction, GFP-(GA) $)_{50}$ accumulated in both soluble and insoluble fractions as high molecular weight species (Fig. 2e), akin to the high molecular weight bands of recombinant GST$(\mathrm{GA})_{50}$ noted above. Such high molecular weight species were also detected in lysates from cells expressing ATG$(\mathrm{GA})_{50}$-HA, ATG-(GA) $50^{-V 5}$ or ATG-(GA) $100^{-V} 5$, again ruling-out the possibility that formation of high molecular weight poly(GA) proteins is driven by the tag to which it is fused (Online Resource $4 b$ and $d$ ).

The purpose of generating a vector that encodes a synthetic repeat sequence for the expression of GFP-(GA) specifically one in which a random nucleotide was introduced in the 3rd and 6th codon positions (GGXGCX), was to enable the evaluation of poly(GA) protein toxicity without the confounding contribution of RNA foci or other c9RAN proteins, the production of which may depend on the secondary structure of $\mathrm{G}_{4} \mathrm{C}_{2}$ repeat-containing RNA [23, 57, 64, 77]. To confirm that the RNA encoded by the synthetic sequence does not result in foci formation, RNAFISH of GFP-(GA) $)_{50}$-expressing cells was undertaken. As above, poly(GA) inclusions were observed in cells expressing GFP-(GA) ${ }_{50}$, but no RNA foci were detected (Fig. 2f). Conversely, both foci and poly(GA) inclusions were found in cells expressing GFP-c9(GA) $)_{50}$, which encodes 50 unadulterated $\mathrm{G}_{4} \mathrm{C}_{2}$ repeats (Fig. 2f). Next, to confirm that our synthetic $(\mathrm{GA})_{50}$ sequence does not undergo RAN translation, we generated expression vectors containing the $(\mathrm{GA})_{50}$ sequence with or without an ATG start codon. 

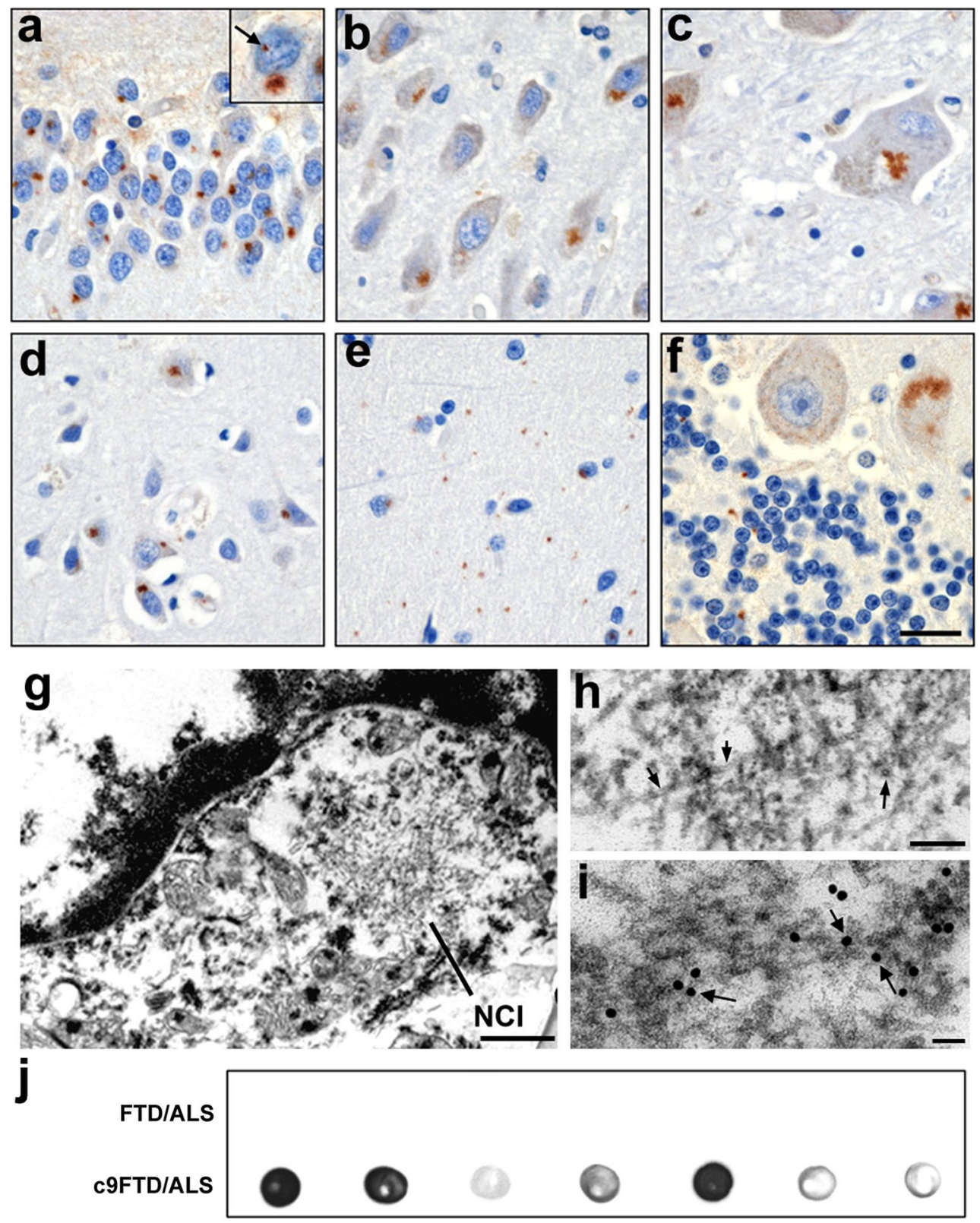

Fig. 1 Neuropathology of c9RAN poly(GA) proteins in C9ORF72 repeat expansion cases. a-f Immunohistochemical analysis shows that poly(GA) proteins accumulate throughout the central nervous system of C9ORF72 repeat expansion carriers as neuronal cytoplasmic inclusions and neuronal intranuclear inclusions (arrow in insert, a). Regions with a particularly high burden include the dentate fascia of the hippocampus (a; Case 8), the hippocampus proper (b; CA3/2; Case 10), the anterior thalamus (c; Case 4), the frontal cortex (d; Layers IV-V; Case 7), the cerebellar molecular layer (e; Case 1) and the cerebellar internal granule cell layer (f; Case 9). Scale bar represents

The vectors include six stop codons upstream of $( \pm)$ ATG$(\mathrm{GA})_{50}$ (two in each reading frame) to prevent ATG-initiated translation from the vector sequence, and a different tag in each reading frame downstream of $( \pm)$ ATG- $(\mathrm{GA})_{50}$ to monitor protein expression in all frames [i.e., frame 1 :
$25 \mu \mathrm{m}(\mathbf{a}-\mathbf{e})$ and $20 \mu \mathrm{m}$ (f). Regular electron microscopy (EM) of granule cells of the cerebellar cortex from a c9FTD-MND case shows that cytoplasmic inclusions (g) are composed of 15-17 nm filaments (arrow, h). Immuno-EM with anti-poly(GA) antibody labeled with gold particles $(18 \mathrm{~nm})$ reveals poly $(\mathrm{GA})$ proteins localize to filaments (arrow, i). Scale bars represent $0.5 \mu \mathrm{m}(\mathbf{g}), 100 \mathrm{~nm}(\mathbf{h})$, and $50 \mathrm{~nm}$ (i). j Dot blot reveals that anti-poly(GA) immunoreactivity in cerebellar urea fractions is specific to c9FTD/ALS. Each dot represents one case

$(\mathrm{GA})_{50}-\mathrm{HA}$; frame 2: novel RAN protein-Myc; frame 3: novel RAN protein-Flag] (Online Resource 4a). Western blot analysis revealed that cells transfected with the ATG$(\mathrm{GA})_{50}-3 \mathrm{~T}$ expression vector produce $(\mathrm{GA})_{50}$-HA proteins but not Myc- or Flag-tagged proteins RAN translated from 

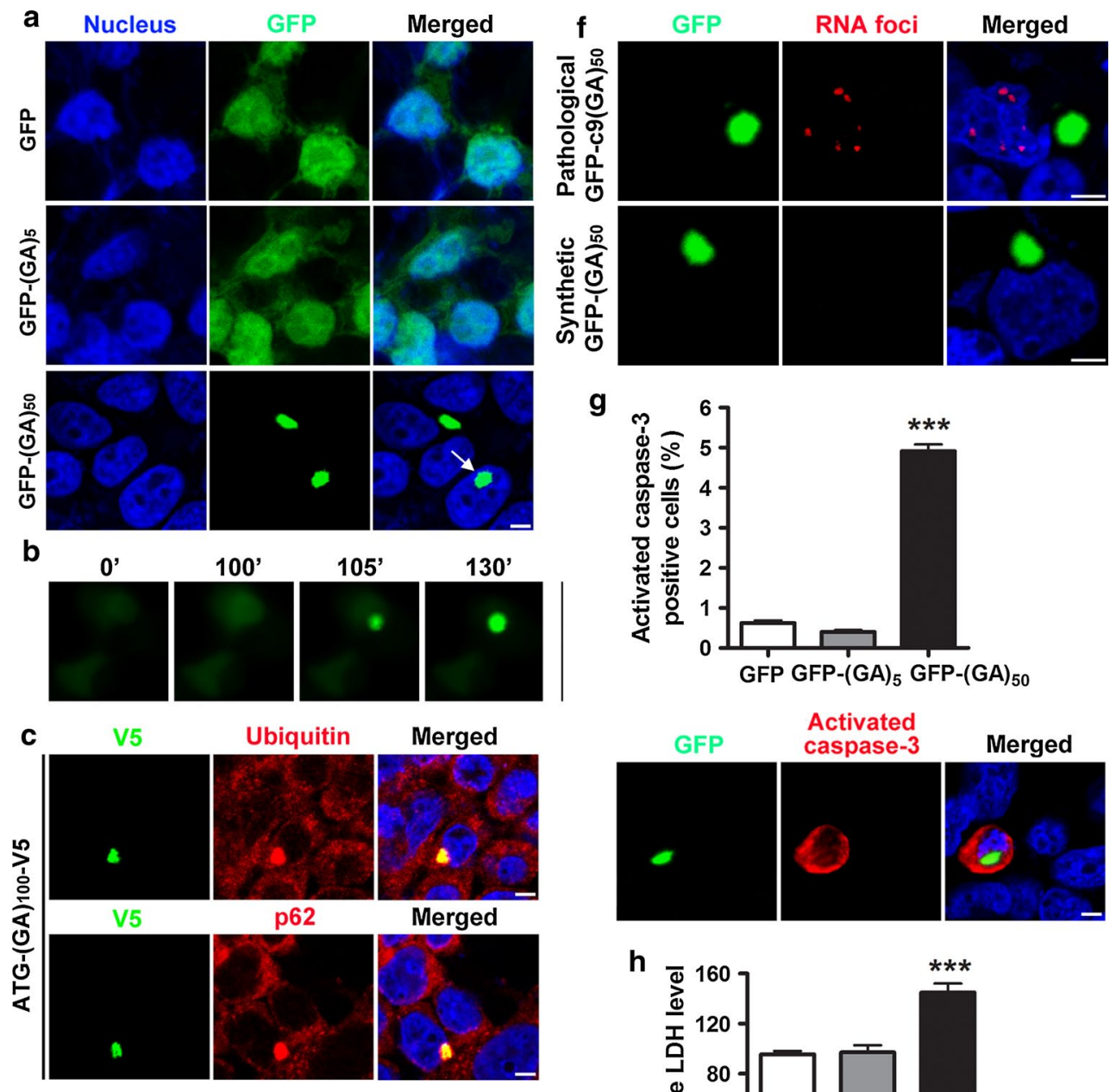

Ubiquitin
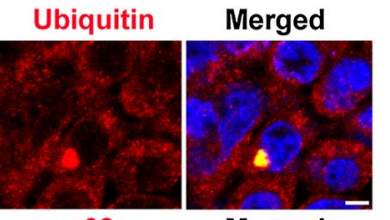

p62

Merged

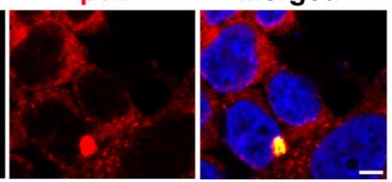

d

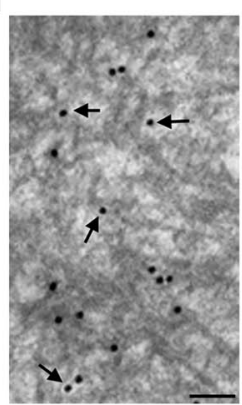

e GFP GFP-(GA) 50

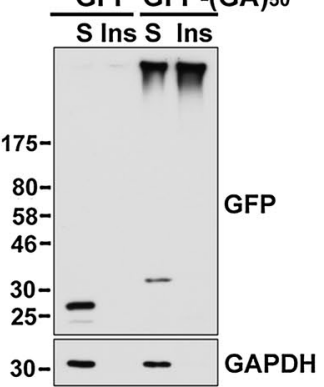

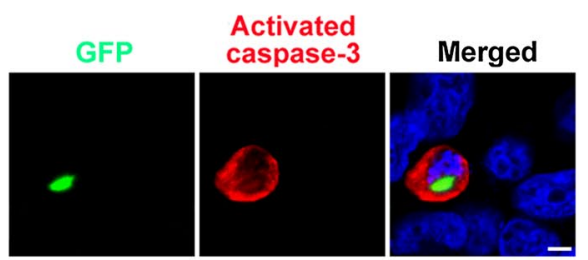

h

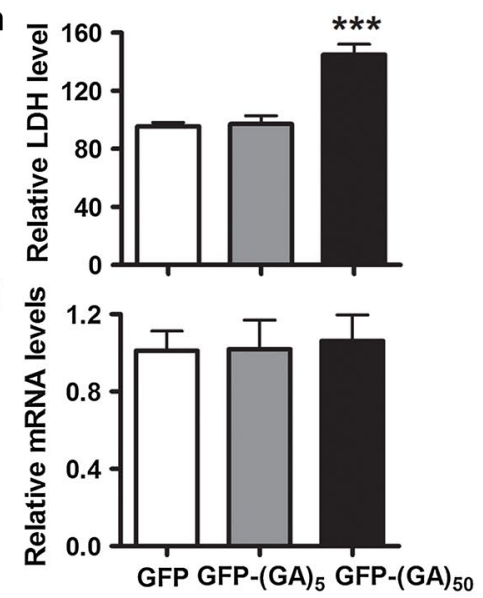

was used. Post-transfection, cells were subjected to RNA fluorescence in situ hybridization (FISH) to visualize RNA foci. GFP$(\mathrm{GA})_{50}$ expression leads to the formation of poly(GA) inclusions, but transcripts from this sequence do not form RNA foci. In contrast, both RNA foci and poly(GA) inclusions are formed in cells that express GFP-c $9(\mathrm{GA})_{50}$. Scale bar represents $5 \mu \mathrm{m}$. g Quantitative analysis and representative image showing that cells bearing inclusions of GFP-(GA) ${ }_{50}$ are immunoreactive for activated caspase-3, a crucial mediator of cell death. Scale bar represents $5 \mu \mathrm{m}$. h LDH activity in media, an indicator of cell toxicity, is increased in cells expressing GFP-(GA) ${ }_{50}$. i Transgene mRNA levels are comparable among cells expressing GFP, GFP-(GA) 5 and GFP-(GA) $)_{50}$. Data represent the mean \pm SEM from sixteen random selected fields $(\mathbf{g})$ or three separate experiments (h and $\mathbf{i}$ ). ${ }^{* * *} P<0.001$, as analyzed by one-way analysis of variance followed by Tukey's post hoc analysis 
reading frames 2 or 3 (Online Resource 4b). Moreover, no proteins were expressed from any of the three reading frames in cells transfected with the ATG-free $(\mathrm{GA})_{50}-3 \mathrm{~T}$ vector (Online Resource $4 \mathrm{~b}$ ), despite comparable transgene mRNA levels in ATG-(GA) $)_{50}-3 \mathrm{~T}$ and $(\mathrm{GA})_{50^{-}} 3 \mathrm{~T}$ expressing cells (Online Resource 4c). Together, our results indicate that our synthetic $(\mathrm{GA})_{50}$ sequence is not RAN translated and results only in the production of poly $(\mathrm{GA})$ proteins.

Having excluded the potential involvement of foci formation and RAN translation in our poly(GA)-expressing cellular model, we next evaluated whether poly(GA) expression and aggregation are associated with cellular toxicity using caspase- 3 activation as an indicator of cell death. Compared to the $0.6 \%$ of GFP- or GFP-(GA) $)_{5}$-expressing cells that showed signs of activated caspase-3, the percentage of cells positive for activated caspase- 3 was approximately eightfold higher upon expression of GFP-(GA) $5_{50}$ (Fig. 2g, Online Resource 4e). Increased activation of caspase-3 was similarly observed in cells bearing inclusions of $(\mathrm{GA})_{50}-\mathrm{V} 5$, (GA) ${ }_{100^{-}} \mathrm{V} 5$ or $(\mathrm{GA})_{50}$-HA (Online Resource 4f). Poly(GA)-induced cytotoxicity was further confirmed by increased LDH levels in culture media of GFP-(GA) $)_{50^{-}}$ expressing cells compared to LDH levels in media from cells expressing either GFP alone or GFP-(GA) ${ }_{5}$ (Fig. 2h), despite comparable levels of transgene mRNA (Fig. 2i).

Expression of poly $(\mathrm{GA})$ proteins causes ER stress and neuronal death

Since GFP-(GA) $)_{50}$ expression in immortalized cultured cells caused a modest, but statistically significant, increase in caspase activation, we next sought to determine whether expression of poly(GA) proteins in primary neurons would result in inclusion formation and a similar or greater degree of toxicity. To this end, we generated adeno-associated viral vectors (AAV1) for the expression of GFP or GFP$(\mathrm{GA})_{50}$ for transduction of primary mouse cortical neurons at day in vitro 4. Seven days later, increased LDH levels were observed in medium from neurons expressing GFP$(\mathrm{GA})_{50}$ but not GFP (Fig. 3a), despite comparable levels of transgene mRNA (Fig. 3b). Additional signs of toxicity observed specifically in GFP-(GA) ${ }_{50}$-expressing neurons included caspase- 3 activation in cells harboring inclusions (Fig. 3c-e) and stunted neurite outgrowth (Online Resource $5 \mathrm{a}$ and $\mathrm{b}$ ). Impaired neurite outgrowth was also observed in primary neurons expressing ATG-(GA) $100^{-V} 5$ (Online Resource $5 \mathrm{a}$ and $\mathrm{b}$ ), the expression of which resulted in the formation of poly $(\mathrm{GA})$ inclusions positive for ubiquitin and p62 (Online Resource 5c).

Similarly to our findings above, immuno-EM studies showed that poly(GA) inclusions in GFP- $(\mathrm{GA})_{50}$-expressing neurons were composed of filaments (arrow, Online Resource $5 \mathrm{~d}$ ), and that the expression of GFP-(GA) $5_{50}$, but not GFP alone, resulted in the formation of high molecular weight species (Fig. 3d). GFP-(GA) $)_{50}$ expression was also associated with the accumulation of ubiquitinated proteins (Fig. 3d), suggesting that poly(GA) proteins impair the activity of the ubiquitin-proteasome system (UPS). Indeed, proteasome activity was found to be significantly decreased in neurons expressing GFP-(GA) $)_{50}$ compared to those expressing GFP (Fig. 3f).

Since it is well established that proteasome inhibition causes ER stress [17, 32, 47, 50, 53], our findings may indicate that expression of poly $(\mathrm{GA})$ proteins leads to ER stress. Although poly(GA) inclusions did not localize to the ER-Golgi secretory compartment (Online Resource 5e), poly(GA) expression nonetheless increased levels of binding immunoglobulin protein (BIP), an ER chaperone protein, phosphorylated protein kinase RNA (PKR)-like ER kinase (PERK), a critical transducer of ER stress, and transcriptional factor C/EBP homologous protein (CHOP), a downstream target of PERK (Fig. 3d, e), indicative of activation of the PERK-CHOP ER stress-associated signaling pathway. However, poly(GA) expression did not influence other pathways normally triggered by ER stress; neither induction of the activating transcription factor 6 (ATF6) axis, assessed by ATF6 cleavage (Fig 3d, e), nor of the inositol-requiring protein-1 (IRE1) axis, assessed by abnormal X-box-binding protein 1 (XBP1) splicing (Fig. 3g, h), were observed in neurons expressing GFP-(GA) $)_{50}$. As a positive control, non-transduced neurons were treated with tunicamycin, an ER stress inducer. This resulted in increased levels of BIP, PERK and CHOP (Online Resource $5 \mathrm{f}$ and $\mathrm{g}$ ), as well as abnormal splicing of XBP1 (Fig. 3g, h), but not ATF6 cleavage (Online Resource $5 \mathrm{f}$ and $\mathrm{g}$ ), suggesting that the ATF6 pathway is less likely to be activated upon ER stress in primary neurons. Of interest, tunicamycin treatment resulted in the accumulation of ubiquitinated proteins (Online Resource $5 \mathrm{~g}$ ) without direct inhibition of proteasome activity (Fig. 3f), suggesting increased ubiquitination of misfolded proteins in the ER.

Like GFP-(GA) $)_{50}$ expression, expression of ATG(GA) $100^{-V} 5$ or exposure of neurons to the proteasome inhibitor, MG-132, resulted in the accumulation of ubiquitinated proteins, impairment of proteasome activity, as well as activation of caspase- 3 and the PERK-CHOP pathway (Fig. 3f, Online Resource $5 \mathrm{f}$ and $\mathrm{g}$ ). These findings provide further support that poly(GA) expression in primary neurons inhibits proteasome activity and leads to ER stress. We thus evaluated whether signs of heightened ER stress are observed in C9ORF72 repeat expansion carriers. Given that TDP-43 pathology has been associated with ER stress $[68,70]$, and that both c9RAN protein pathology and TDP43 pathology are present in c9ALS, we compared c9ALS cases to sporadic ALS cases with TDP-43 pathology to exclude the potentially confounding effect of TDP-43 on 

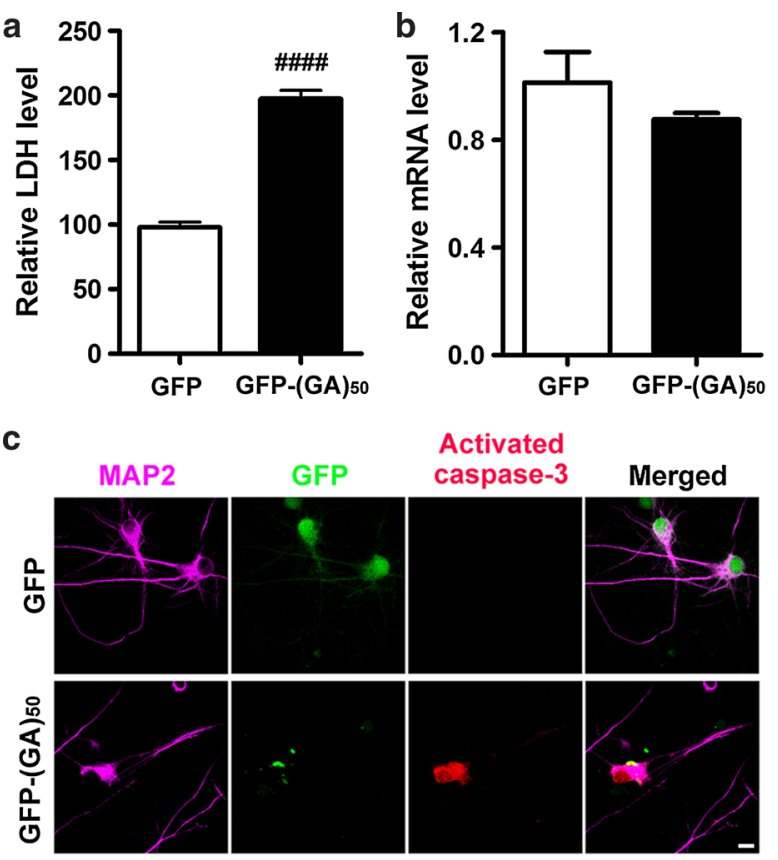

f
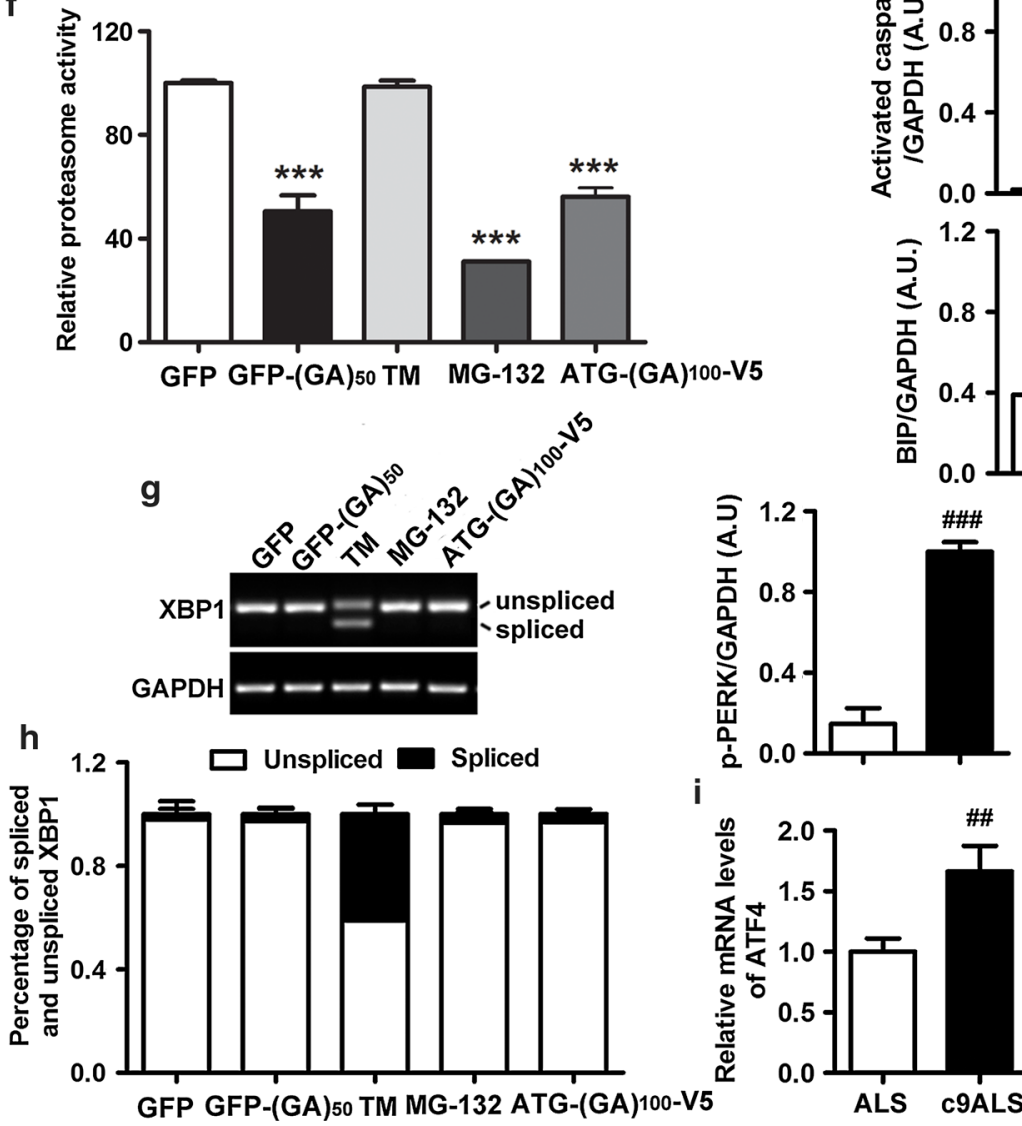
i
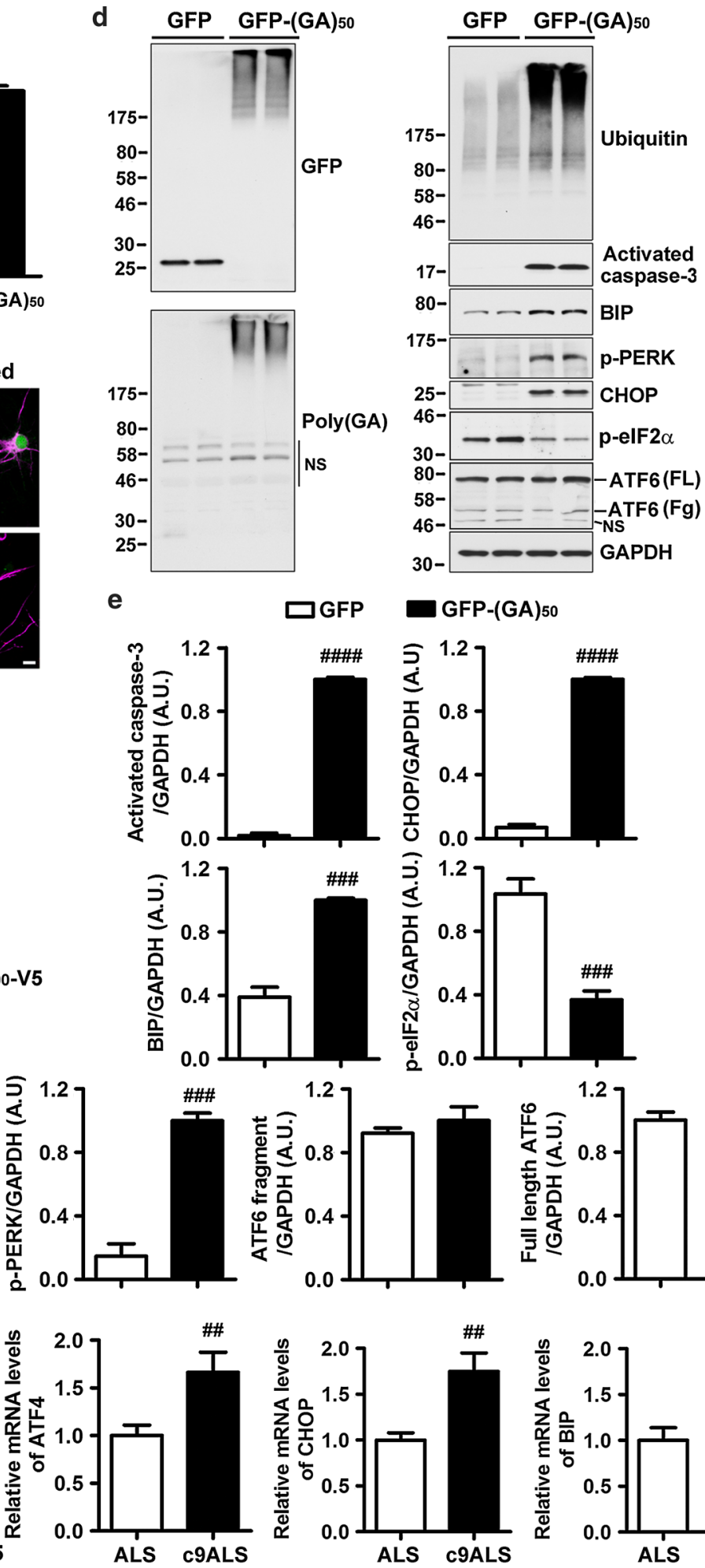

e

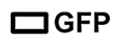

GFP-(GA)50
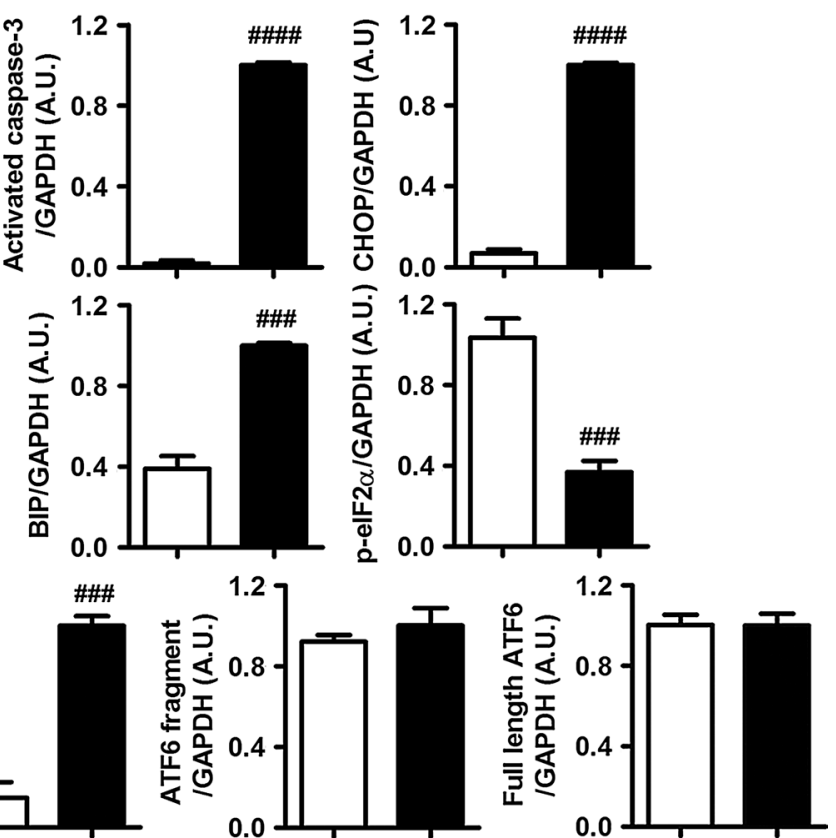

ER stress. We also chose to examine activating transcription factor 4 (ATF4) and CHOP, two ER stress markers involved in the PERK-CHOP pathway, given that poly(GA) protein expression in primary neurons specifically activates this pathway. Of importance, quantitative PCR analysis revealed that mRNA levels of ATF4 and CHOP were significantly increased in frontal cortex of c9ALS cases (Fig. 3i). BIP levels, however, did not differ (Fig. 3i). 
4 Fig. 3 Expression of poly(GA) proteins in primary neurons causes neurotoxicity accompanied by UPS impairment and ER stress. a Expression of GFP-(GA) $)_{50}$, but not GFP, causes toxicity, as assessed by measuring LDH activity in media. b Transgene mRNA levels are comparable in neurons expressing GFP and GFP-(GA) $)_{50}$. c Activated caspase-3 is observed in MAP2-positive neurons bearing GFP-(GA) $)_{50}$ inclusions. Scale bar represents $10 \mu \mathrm{m}$. Western blot (d) and densitometric analysis of blots (e) show that expression of GFP-(GA) s0 $_{50}$ in primary neurons leads to increased levels of activated caspase-3 and ubiquitinated proteins. In addition, levels of the ER stress markers, BIP, phospho-PERK and CHOP, are increased by GFP-(GA) expression, whereas levels of phospho-eIF $2 \alpha$ are decreased and ATF6 levels remain unchanged. $F L, F g$ bands corresponding to full-length and fragmented ATF6, respectively. NS non-specific bands. f Proteasome activity assays reveal that expression of poly(GA) proteins inhibit proteasome activity. Decreased proteasome activity is also observed in neurons treated with the proteasome inhibitor MG-132, but not with the ER stress inducer, tunicamycin. RT-PCR (g) and quantitative analysis (h) show that tunicamycin induces abnormal splicing of XBP1. However, expression of poly(GA) proteins or treatment with MG-132 does not result in this alteration. i mRNA levels of ER stress markers, ATF4 and CHOP, are significantly increased in frontal cortex of ALS patients with the C9ORF72 repeat expansion. $N=8$ for c9ALS and $N=11$ for sporadic ALS without the C9ORF72 repeat expansion. Data represents mean \pm SEM of three separate experiments $(\mathbf{a}, \mathbf{b}, \mathbf{e}, \mathbf{f}, \mathbf{h}) .{ }^{\# \#} P<0.01,{ }^{\# \#} P<0.001$ and

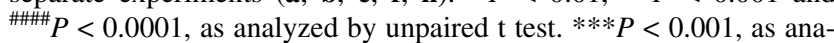
lyzed by one-way analysis of variance followed by Tukey's post hoc analysis

ER stress inhibitors, salubrinal and TUDCA, provide rescue against poly(GA)-induced ER stress and neurotoxicity

Since cell death associated with the PERK-CHOP signaling pathway is partially mediated through the dephosphorylation of eukaryotic translation initiation factor $2 \alpha$ (eIF $2 \alpha$ ), which is regulated by the association of growth arrest and DNA damage inducible 34 (GADD34) with protein phosphatase 1 (PP1C) [24, 25, 42, 49], we examined the phosphorylation status of eIF2 $\alpha$ in neurons expressing GFP-(GA) $)_{50}$. Western blot analysis revealed that, compared to GFP expression, expression of GFP-(GA) $)_{50}$ significantly reduced eIF $2 \alpha$ phosphorylation (Figs. 3d, e, 4b, c). We thus evaluated the neuroprotective effects of salubrinal, a selective inhibitor of the GADD34-PP1C complex known to offer protection from ER stress-associated cell death $[9,36$, 60], in neurons expressing GFP-(GA) $)_{50}$. Compared to vehicle-treated GFP-(GA) $)_{50}$-expressing neurons, LDH activity in media (Fig. 4a) and caspase-3 activation (Fig. 4b, c) were significantly decreased in neurons treated with salubrinal $(2.5$ and $5 \mu \mathrm{M})$. This was accompanied by a dramatic increase in eIF $2 \alpha$ phosphorylation (Fig. 4b, c), indicating that salubrinal efficiently inhibits the activity of the GADD34-PP1C complex. Moreover, salubrinal at $5 \mu \mathrm{M}$ decreased levels of BIP and phospho-PERK (Fig. 4b, c), although neither levels of GFP-(GA) $)_{50}$ mRNA and protein, ubiquitinated proteins, nor CHOP were altered (Fig. 4b-e).
To further evaluate the role of ER stress in poly(GA)induced toxicity, neurons expressing GFP- $(\mathrm{GA})_{50}$ were treated with the chemical chaperone TUDCA, an inhibitor of ER stress and associated toxicity [13, 38, 52, 72]. Compared to vehicle-treated neurons expressing GFP-(GA) $)_{50}$, those treated with TUDCA $(0.25$ and $0.5 \mathrm{mM})$ showed a significant decrease in LDH activity in media (Fig. 5a) and caspase-3 activation (Fig. 5b, c). In addition, a dramatic decrease in phospho-PERK and CHOP levels were observed (Fig. 5b, c). Conversely, levels of GFP-(GA) $)_{50}$ mRNA and protein, ubiquitinated proteins, and BIP were not altered by TUDCA treatment (Fig. 5b-e). Taken together, these findings indicate that inhibitors of ER stress provide protection against poly(GA) neurotoxicity.

\section{Discussion}

RAN translation is becoming a well-established phenomenon in many repeat expansion disorders [3, 44, 65, 77]. Inclusions composed of RAN-translated proteins are now considered a neuropathological hallmark of c9FTD/ALS $[3,20,43,44,78]$, but the contribution of this unconventional form of translation to disease pathogenesis has so far been enigmatic. While each c9RAN protein may influence neuronal health differently, herein we provide evidence that poly(GA) proteins are neurotoxic and could thus be implicated in the neurodegenerative processes of c9FTD/ALS.

Using cultured cells as a model to express c9RAN proteins of 50 repeating dipeptides, we observed that poly(GA) proteins formed ubiquitin- and p62-positive cytoplasmic inclusions, recapitulating the poly $(\mathrm{GA})$ pathology of c9FTD/ALS $[2,44]$. In contrast, GFP-(PA) $)_{50}$ and GFP-(GP) $)_{47}$ remained diffusely distributed, whereas GFP$(\mathrm{GR})_{50}$ and GFP-(PR $)_{50}$ aggregated in the nucleus, perhaps as a result of repeat length and the fact that arginine (R)-rich regions can function as a nuclear localization signal. Because most poly(GR) and poly(PR) inclusions in c9FTD/ALS patients are cytoplasmic [20, 43, 44, 78], the exclusively nuclear localization of GFP-(GR $)_{50}$ and GFP$(\mathrm{PR})_{50}$ inclusions in cultured cells does not accurately reflect c9FTD/ALS neuropathology. These studies indicate that poly(GA) proteins are highly aggregation-prone compared to the other $\mathrm{c} 9 \mathrm{RAN}$ proteins, and that, depending on the model, longer repeat lengths should be used to evaluate poly(GP), poly(GR), poly(PA), and poly(PR) aggregation and toxicity to better mimic c9FTD/ALS.

To study the neuropathologic profile of poly(GA) inclusions in c9FTD/ALS, we generated a novel anti-poly(GA) antibody using as the antigen-purified recombinant GST$(\mathrm{GA})_{50}$, which formed high molecular weight material and filaments in vitro. Consistent with previous reports [40, 44, $56]$, we found that poly $(\mathrm{GA})$ proteins were highly insoluble 
Fig. 4 Salubrinal, a selective inhibitor of eIF $2 \alpha$ dephosphorylation, protects neurons against poly(GA)-induced ER stress and toxicity. a Salubrinal, a small molecule known to provide rescue from ER stress and associated cell death by inhibiting the dephosphorylation of eIF $2 \alpha$, significantly decreases LDH activity in media of neurons expressing GFP$(\mathrm{GA})_{50}$. Western blot (b) and densitometric analysis of blots (c) show that treatment of GFP(GA) ${ }_{50}$-expressing neurons with salubrinal significantly inhibits caspase- 3 activation, increases eIF $2 \alpha$ phosphorylation, and decreases levels of ER stress markers, BIP and phosphoPERK. Note that salubrinal treatment does not decrease levels of ubiquitinated proteins or CHOP. Levels of GFP$(\mathrm{GA})_{50}$ protein and mRNA are also not changed after salubrinal treatment, as shown by Western blot (b), densitometric analysis of blot (d), and qRT-PCR (e). $N S$ indicates non-specific bands. Data represents mean \pm SEM from three separate experiments. $* P<0.05, * * P<0.01$ and $* * * P<0.001$, as analyzed by one-way analysis of variance followed by Tukey's post hoc analysis
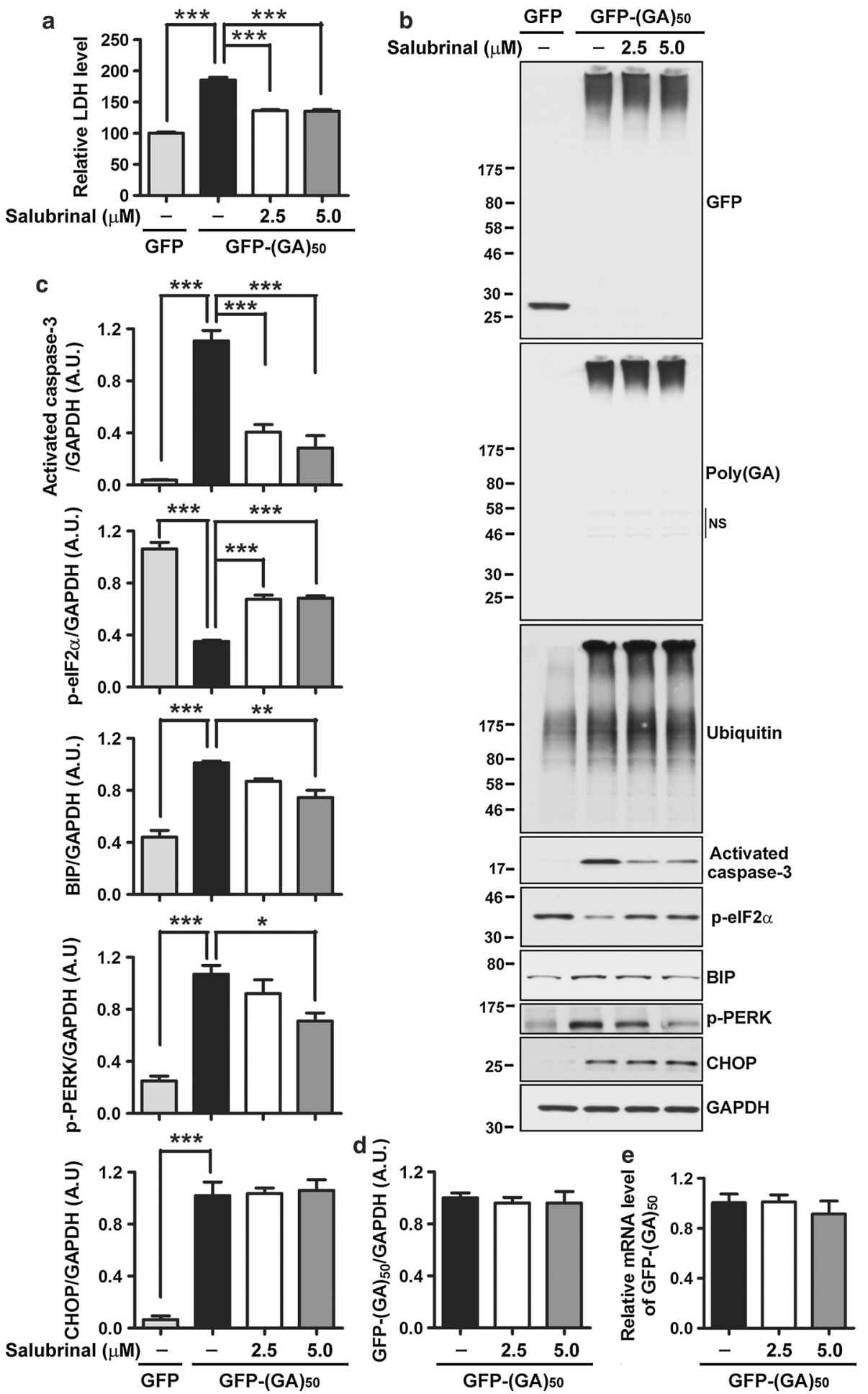

in c9FTD/ALS brain tissue, and that anti-poly(GA) immunoreactive inclusions were abundant throughout the CNS. To our knowledge, we are the first to report that poly(GA) proteins form filamentous structures in c9FTD/ALS brain tissue. Similar filamentous structures were produced in experimental models; we show that poly(GA) proteins with as little as 50 dipeptide-repeats self-assembled and formed filaments in vitro, as well as in cultured cells and primary neurons. It was with some surprise that we found, using fluorescent microscopy of live cells, that poly(GA) proteins quickly (within mere minutes) converted from a diffuse distribution to compact, small aggregates. Perhaps this rapid transformation occurs when the concentration of poly(GA) proteins within a localized area meets a critical 
Fig. 5 The chemical chaperone TUDCA protects neurons against poly(GA)-induced ER stress and toxicity. a TUDCA, a chemical chaperone known to inhibit ER stress and associated downstream pathways, significantly decreases LDH activity in media of neurons expressing GFP-(GA) $)_{50}$. b, c Treatment of GFP-(GA) $)_{50}$-expressing neurons with TUDCA also significantly inhibits caspase- 3 activation, and decreases levels of ER stress markers, phosphoPERK and CHOP, as shown by Western blot (b) and densitometric analysis of blots (c). Note that TUDCA treatment does not decrease levels of ubiquitinated proteins and BIP $(\mathbf{b}, \mathbf{c})$. Protein and mRNA levels of GFP-(GA) $)_{50}$ are not changed after TUDCA treatment $(\mathbf{d}, \mathbf{e})$. NS non-specific bands. Data represents mean \pm SEM from three separate experiments. $* P<0.05, * * P<0.01$ and $* * * P<0.001$, as analyzed by one-way analysis of variance followed by Tukey's post hoc analysis a

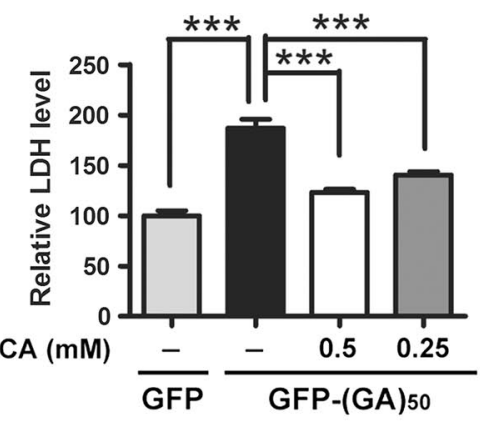

b
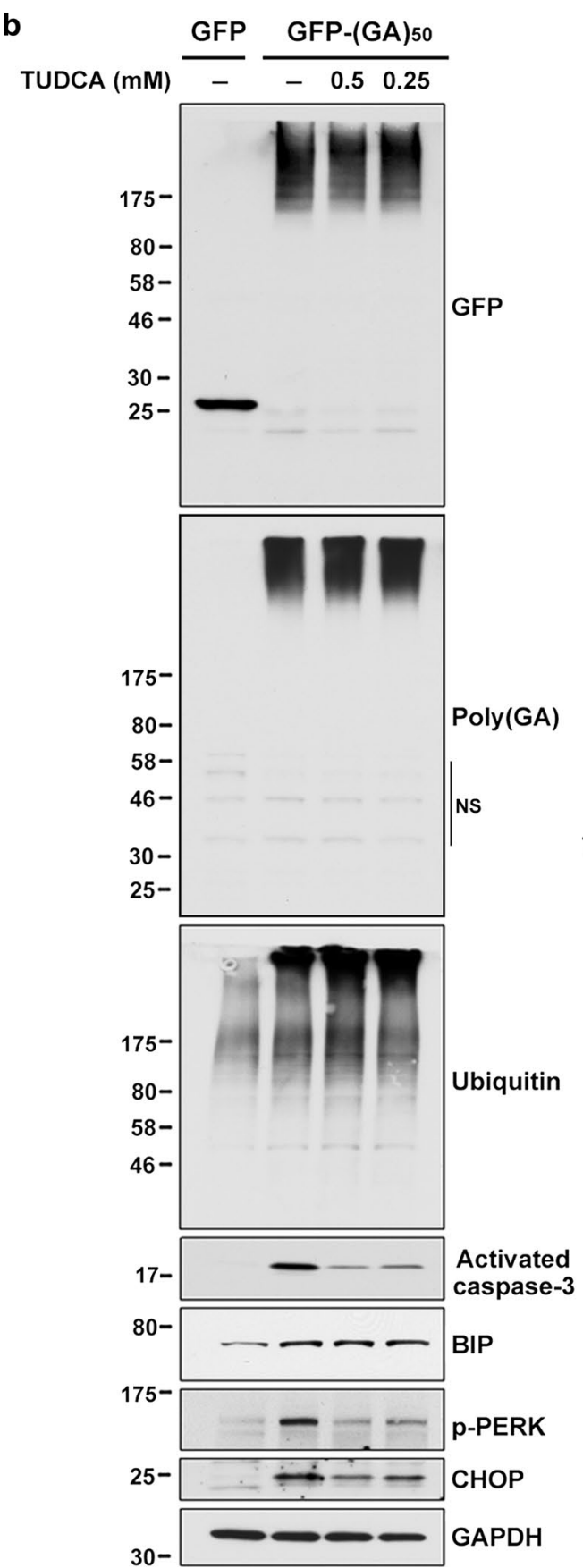

C
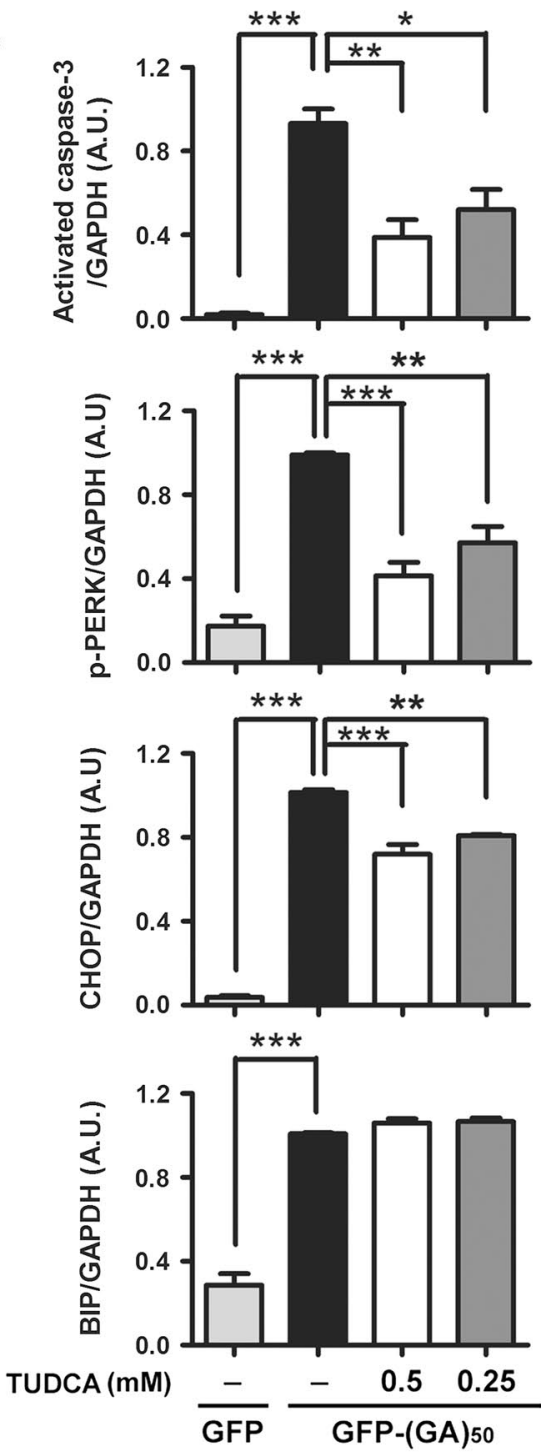

d

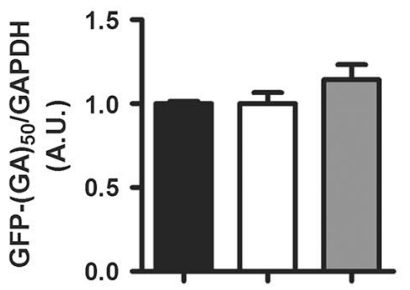

e

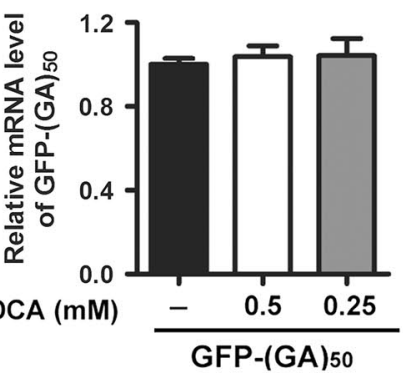


threshold. These small aggregates may then serve to seed the aggregation of soluble poly(GA) proteins, thus causing larger inclusions to form. Poly(GA) may similarly seed the aggregation of other proteins, including c9RAN proteins, given that poly $(\mathrm{GA})$ proteins have been shown to co-localize with various c9RAN proteins in neuronal inclusions in c9FTD/ALS [43, 44]. Like poly(GA) proteins, polyA proteins form high molecular weight species and inclusions in spinocerebellar ataxia type 8 (SCA8) [77], further indicating that proteins with long stretches of hydrophobic residues are especially aggregation-prone.

Cultured cell and primary neuron models provide evidence that expression and aggregation of poly(GA) proteins cause cellular toxicity. Compared to cells expressing GFP-(GA) $)_{5}$, which remained diffusely localized, there was enhanced cytotoxicity in cells expressing GFP$(\mathrm{GA})_{50}$, which formed cytoplasmic inclusions. The majority of GFP-(GA) 50 -expressing cells immunopositive for active caspase-3 contained such inclusions, suggesting that poly(GA) aggregation drives cell death. Nonetheless, it remains possible that soluble and insoluble poly(GA) oligomers also play a toxic role, as is speculated to be the case of inclusion-forming proteins, such as tau and TDP43 , in other neurodegenerative diseases. Whatever the neurotoxic poly(GA) species may be, our studies demonstrate that this c9RAN protein impairs function of the UPS in primary neurons. Compared to neurons expressing GFP alone, proteasome activity was significantly decreased in neurons expressing GFP-(GA) $)_{50}$, and this was accompanied with a dramatic accumulation of ubiquitinated proteins. These findings are consistent with reports demonstrating that protein aggregates and/or oligomers can impair the UPS [6, 7, $30,35,71]$.

ER-associated protein degradation (ERAD), which controls protein homeostasis in the ER, is dependent on proper UPS activity [10, 12]; consequently, inhibition of the UPS impairs ERAD, leading to the accumulation of misfolded proteins in the ER and ER stress [17, 32, 47, 50, 53, 74]. Under conditions of ER stress, BIP, a master regulator of the unfolded protein response (UPR) that normally binds to and inhibits activity of ER stress sensors, PERK, ATF6 and IRE1, dissociates from these proteins. This disassociation leads to the activation of different downstream signaling pathways such as PERK auto-phosphorylation, ATF6 cleavage and XBP-1 splicing [25, 67]. Of note, the PERKCHOP pathway was selectively activated in primary neurons expressing GFP-(GA) $)_{50}$, as evidenced by increased levels of the ER sensor phospho-PERK, and its downstream target CHOP. Selective activation of the PERK-CHOP pathway was similarly observed in non-transduced neurons treated with the proteasome inhibitor, MG-132. Other similarities between GFP-(GA) $)_{50}$ expression and MG-132-induced proteasome inhibition include the accumulation of ubiquitinated proteins, decreased proteasome activity, and caspase- 3 activation. In contrast, treatment of neurons with tunicamycin, an ER stress inducer, activated both PERKCHOP and IRE-XBP1 pathways without impairing proteasome activity. Together, our findings suggest that poly(GA) proteins indirectly induce ER stress through proteasome inhibition. Of importance, we show that mRNA levels of ER stress markers of the PERK-CHOP pathway, ATF4 and CHOP, are significantly increased in c9ALS cases compared to sporadic ALS cases without the C9ORF72 repeat expansion. While no difference in BIP mRNA levels were observed, this may be due to the shared TDP-43 pathology between C9ORF72-positive and -negative ALS, which has been associated with ER stress $[68,70]$. In addition to our findings using human postmortem samples, it is also worth noting that a recent study reported that iPSC-derived motor neurons from c9ALS patient, which contain RNA foci and c9RAN proteins but no TDP-43 pathology [15], exhibit an increased vulnerability to tunicamycin [23], supporting the association between the C9ORF72 repeat expansion and ER stress. Future studies investigating whether, like poly(GA) proteins, RNA foci and other c9RAN proteins inhibit proteasome activity and cause ER stress are warranted.

ER stress activation of the PERK-CHOP pathway is well documented (see [25, 67] for review). In brief, PERK is activated through auto-phosphorylation upon release from BIP. Upon activation, PERK phosphorylates eIF2 $\alpha$ to attenuate global protein synthesis as a pro-survival mechanism. However, phosphorylation of eIF $2 \alpha$ selectively allows the translation of ATF4 and CHOP, which induce cell death under prolonged ER stress. This can occur through multiple mechanisms that include expression of pro-apoptotic genes, promotion of protein synthesis, production of reactive oxygen species (ROS) and ATP depletion [18, 24, 25, 42, 51, 63]. For example, ATF4 and CHOP up-regulate levels of GADD34, which forms a complex with PP1C to dephosphorylate eIF $2 \alpha$; the dephosphorylation of eIF $2 \alpha$ in turn enhances protein synthesis, ATP depletion and ROS production, which consequently induce cell death [24, 42]. The importance of this pathway is further validated by studies showing selective inhibitors of the GADD34-PP1C complex protect cells from ER stress-induced cell death [9, 66]. Consistent with these findings, we show that salubrinal, a selective inhibitor of the GADD34-PP1C complex $[9,36,60]$, restored eIF $2 \alpha$ phosphorylation, reduced ER stress and increased cell survival in neurons expressing poly(GA) proteins. In addition, TUDCA, an inhibitor of ER stress [13, 38, 52, 72], blocked the increase in phospho-PERK and CHOP normally observed in poly(GA)expressing neurons, and provided neuroprotection against poly(GA)-induced toxicity. Of interest, the levels of poly $(\mathrm{GA})$ and ubiquitinated proteins were not themselves 
decreased after salubrinal and TUDCA treatment, suggesting that proteasome inhibition, the culprit responsible for inducing ER stress, remained present in these cells. This may explain why levels of BIP, which correlate with the amount of misfolded proteins in the ER, were not altered following treatment of GFP-(GA) $)_{50}$-expressing cells with TUDCA. As a chemical chaperone, TUDCA may have bound to these misfolded proteins and caused the release of BIP, which then became free to interact with PERK and inhibit PERK auto-phosphorylation and activation. As a result, CHOP levels decreased as did caspase-3 activation. However, BIP levels remain unchanged because TUDCA did not eliminate the accumulation of misfolded proteins, but rather targeted downstream events only. Conversely, salubrinal treatment would have decreased protein translation by enhancing eIF $2 \alpha$ phosphorylation, thus reducing the misfolded protein load in the ER. Consequently, this would cause a decrease in levels of BIP and phosphoPERK, and increase cell survival. That CHOP levels were not also decreased by salubrinal treatment may result from the increase in eIF $2 \alpha$ phosphorylation, which regulates CHOP expression.

In summary, we have generated a novel poly $(\mathrm{GA})$ antibody and confirmed that abundant poly(GA) neuronal inclusions are detected throughout the CNS of c9FTD/ALS cases. We show that poly(GA) proteins are highly aggregation-prone and form filamentous structures in experimental models and c9FTD/ALS brain tissue. Of particular importance, our data provide compelling evidence that poly(GA) proteins contribute to the neurodegeneration in c9FTD/ALS. The expression of poly $(\mathrm{GA})$ proteins causes neurotoxicity; this toxicity occurs in the absence of RNA foci, and is associated with impairment of the UPS and induction of ER stress. ER stress is believed to play an important role in several neurodegenerative diseases, including sporadic ALS [4, 26, 59, 69], and familiar ALS caused by mutations in $\mathrm{Cu} / \mathrm{Zn}$ superoxide dismutase [8, 29, $48,55]$ or vesicle-associated membrane protein-associated protein B [27, 45, 62]. Our data extend the list of diseases involving ER stress, and suggest that targeting the ER, using small molecules such as salubrinal and TUDCA, may be a promising therapeutic approach for c9FTD/ALS.

\footnotetext{
Acknowledgments We are grateful to all patients who agreed to donate postmortem tissue. This work was supported by the National Institutes of Health/National Institute on Aging [R01 AG026251 (L.P.)]; National Institutes of Health/National Institute of Neurological Disorders and Stroke [R21NS074121 (K.B.B. T.F.G.); R21 NS079807 (Y.Z.), R01 NS063964 (L.P.); R01 NS077402 (L.P.), R21 NS084528 (L.P.); P01NS084974 (L.P., D.D., K.B.B., R.R.); R01NS088689 (L.P.)]; National Institute of Environmental Health Services [R01 ES20395 (L.P.)]; Department of Defense [ALSRP AL130125 (L.P.)]; Mayo Clinic Foundation (L.P.); Alzheimer Association [NIRP-14-304425 (Y.Z.)];, Amyotrophic Lateral Sclerosis Association (L.P., T.F.G., Y.Z., V.V.B., K.B.B.), Robert Packard Center for
}

ALS Research at Johns Hopkins (L.P.), Target ALS (L.P.), Canadian Institutes of Health Research (V.V.B.), Siragusa Foundation (V.V.B.), Robert and Clarice Smith \& Abigail Van Buren Alzheimer's Disease Research Foundation (V.V.B.). We acknowledge Luc Pregent and Mary Davis for technical support.

Open Access This article is distributed under the terms of the Creative Commons Attribution License which permits any use, distribution, and reproduction in any medium, provided the original author(s) and the source are credited.

\section{References}

1. Abasolo N, Torrell H, Roig B, Moyano S, Vilella E, Martorell L (2011) RT-qPCR study on post-mortem brain samples from patients with major psychiatric disorders: reference genes and specimen characteristics. J Psychiatr Res 45(11):1411-1418. doi:10.1016/j.jpsychires.2011.06.001

2. Al-Sarraj S, King A, Troakes C, Smith B, Maekawa S, Bodi I, Rogelj B, Al-Chalabi A, Hortobagyi T, Shaw CE (2011) p62 positive, TDP-43 negative, neuronal cytoplasmic and intranuclear inclusions in the cerebellum and hippocampus define the pathology of C9orf72-linked FTLD and MND/ALS. Acta Neuropathol 122(6):691-702. doi:10.1007/s00401-011-0911-2

3. Ash PE, Bieniek KF, Gendron TF, Caulfield T, Lin WL, DejesusHernandez M, van Blitterswijk MM, Jansen-West K, Paul JW 3rd, Rademakers R, Boylan KB, Dickson DW, Petrucelli L (2013) Unconventional translation of C9ORF72 GGGGCC expansion generates insoluble polypeptides specific to c9FTD/ALS. Neuron 77(4):639-646. doi:10.1016/j.neuron.2013.02.004

4. Atkin JD, Farg MA, Walker AK, McLean C, Tomas D, Horne MK (2008) Endoplasmic reticulum stress and induction of the unfolded protein response in human sporadic amyotrophic lateral sclerosis. Neurobiol Dis 30(3):400-407. doi:10.1016/j.nbd.2008.02.009

5. Belzil VV, Bauer PO, Prudencio M, Gendron TF, Stetler CT, Yan IK, Pregent L, Daughrity L, Baker MC, Rademakers R, Boylan K, Patel TC, Dickson DW, Petrucelli L (2013) Reduced C9orf72 gene expression in c9FTD/ALS is caused by histone trimethylation, an epigenetic event detectable in blood. Acta Neuropathol 126(6):895-905. doi:10.1007/s00401-013-1199-1

6. Bence NF, Sampat RM, Kopito RR (2001) Impairment of the ubiquitin-proteasome system by protein aggregation. Science 292(5521):1552-1555. doi:10.1126/science.292.5521.1552

7. Bennett EJ, Bence NF, Jayakumar R, Kopito RR (2005) Global impairment of the ubiquitin-proteasome system by nuclear or cytoplasmic protein aggregates precedes inclusion body formation. Mol Cell 17(3):351-365. doi:10.1016/j.molcel.2004.12.021

8. Bernard-Marissal N, Moumen A, Sunyach C, Pellegrino C, Dudley K, Henderson CE, Raoul C, Pettmann B (2012) Reduced calreticulin levels link endoplasmic reticulum stress and Fas-triggered cell death in motoneurons vulnerable to ALS. J Neurosci 32(14):4901-4912. doi:10.1523/JNEUROSCI.5431-11.2012

9. Boyce M, Bryant KF, Jousse C, Long K, Harding HP, Scheuner D, Kaufman RJ, Ma D, Coen DM, Ron D, Yuan J (2005) A selective inhibitor of eIF2alpha dephosphorylation protects cells from ER stress. Science 307(5711):935-939. doi:10.1126/ science. 1101902

10. Brodsky JL (2012) Cleaning up: ER-associated degradation to the rescue. Cell 151(6):1163-1167. doi:10.1016/j.cell.2012.11.012

11. Chuang DM, Hough C, Senatorov VV (2005) Glyceraldehyde3-phosphate dehydrogenase, apoptosis, and neurodegenerative 
diseases. Annu Rev Pharmacol Toxicol 45:269-290. doi:10.1146/ annurev.pharmtox.45.120403.095902

12. Claessen JH, Kundrat L, Ploegh HL (2012) Protein quality control in the ER: balancing the ubiquitin checkbook. Trends Cell Biol 22(1):22-32. doi:10.1016/j.tcb.2011.09.010

13. de Almeida SF, Picarote G, Fleming JV, Carmo-Fonseca M, Azevedo JE, de Sousa M (2007) Chemical chaperones reduce endoplasmic reticulum stress and prevent mutant HFE aggregate formation. J Biol Chem 282(38):27905-27912. doi:10.1074/jbc.M702672200

14. DeJesus-Hernandez M, Mackenzie IR, Boeve BF, Boxer AL, Baker M, Rutherford NJ, Nicholson AM, Finch NA, Flynn H, Adamson J, Kouri N, Wojtas A, Sengdy P, Hsiung GY, Karydas A, Seeley WW, Josephs KA, Coppola G, Geschwind DH, Wszolek ZK, Feldman H, Knopman DS, Petersen RC, Miller BL, Dickson DW, Boylan KB, Graff-Radford NR, Rademakers R (2011) Expanded GGGGCC hexanucleotide repeat in noncoding region of C9ORF72 causes chromosome 9p-linked FTD and ALS. Neuron 72(2):245-256. doi:10.1016/j.neuron.2011.09.011

15. Donnelly CJ, Zhang PW, Pham JT, Heusler AR, Mistry NA, Vidensky S, Daley EL, Poth EM, Hoover B, Fines DM, Maragakis N, Tienari PJ, Petrucelli L, Traynor BJ, Wang J, Rigo F, Bennett CF, Blackshaw S, Sattler R, Rothstein JD (2013) RNA toxicity from the ALS/FTD C9ORF72 expansion is mitigated by antisense intervention. Neuron 80(2):415-428. doi:10.1016/j. neuron.2013.10.015

16. Franzolin E, Pontarin G, Rampazzo C, Miazzi C, Ferraro P, Palumbo E, Reichard P, Bianchi V (2013) The deoxynucleotide triphosphohydrolase SAMHD1 is a major regulator of DNA precursor pools in mammalian cells. Proc Natl Acad Sci 110(35):14272-14277. doi:10.1073/pnas.1312033110

17. Fribley A, Zeng Q, Wang CY (2004) Proteasome inhibitor PS-341 induces apoptosis through induction of endoplasmic reticulum stress-reactive oxygen species in head and neck squamous cell carcinoma cells. Mol Cell Biol 24(22):9695-9704. doi: 10.1128/MCB.24.22.9695-9704.2004

18. Galehdar Z, Swan P, Fuerth B, Callaghan SM, Park DS, Cregan SP (2010) Neuronal apoptosis induced by endoplasmic reticulum stress is regulated by ATF4-CHOP-mediated induction of the Bcl-2 homology 3-only member PUMA. J Neurosci 30(50):16938-16948. doi:10.1523/JNEUROSCI.1598-10.2010

19. Gass J, Lee WC, Cook C, Finch N, Stetler C, Jansen-West K, Lewis J, Link CD, Rademakers R, Nykjaer A, Petrucelli L (2012) Progranulin regulates neuronal outgrowth independent of sortilin. Mol Neurodegener 7:33. doi:10.1186/1750-1326-7-33

20. Gendron TF, Bieniek KF, Zhang YJ, Jansen-West K, Ash PE, Caulfield T, Daughrity L, Dunmore JH, Castanedes-Casey M, Chew J, Cosio DM, van Blitterswijk M, Lee WC, Rademakers R, Boylan KB, Dickson DW, Petrucelli L (2013) Antisense transcripts of the expanded C9ORF72 hexanucleotide repeat form nuclear RNA foci and undergo repeat-associated non-ATG translation in c9FTD/ALS. Acta Neuropathol 126(6):829-844. doi:10.1007/s00401-013-1192-8

21. Gendron TF, Belzil VV, Zhang YJ, Petrucelli L (2014) Mechanisms of toxicity in C9FTLD/ALS. Acta Neuropathol 127(3):359-376. doi:10.1007/s00401-013-1237-z

22. Giordana MT, Ferrero P, Grifoni S, Pellerino A, Naldi A, Montuschi A (2011) Dementia and cognitive impairment in amyotrophic lateral sclerosis: a review. Neurol Sci 32(1):9-16. doi:10.1007/s10072-010-0439-6

23. Haeusler AR, Donnelly CJ, Periz G, Simko EA, Shaw PG, Kim MS, Maragakis NJ, Troncoso JC, Pandey A, Sattler R, Rothstein JD, Wang J (2014) C9orf72 nucleotide repeat structures initiate molecular cascades of disease. Nature 507(7491):195-200. doi:10.1038/nature13124

24. Han J, Back SH, Hur J, Lin YH, Gildersleeve R, Shan J, Yuan CL, Krokowski D, Wang S, Hatzoglou M, Kilberg MS, Sartor MA,
Kaufman RJ (2013) ER-stress-induced transcriptional regulation increases protein synthesis leading to cell death. Nat Cell Biol 15(5):481-490. doi:10.1038/ncb2738

25. Hetz C (2012) The unfolded protein response: controlling cell fate decisions under ER stress and beyond. Nat Rev Mol Cell Biol 13(2):89-102. doi:10.1038/nrm3270

26. Ilieva EV, Ayala V, Jove M, Dalfo E, Cacabelos D, Povedano M, Bellmunt MJ, Ferrer I, Pamplona R, Portero-Otin M (2007) Oxidative and endoplasmic reticulum stress interplay in sporadic amyotrophic lateral sclerosis. Brain 130(Pt 12):3111-3123. doi:10.1093/brain/awm190

27. Kanekura K, Nishimoto I, Aiso S, Matsuoka M (2006) Characterization of amyotrophic lateral sclerosis-linked P56S mutation of vesicle-associated membrane protein-associated protein B (VAPB/ALS8). J Biol Chem 281(40):30223-30233. doi:10.1074/jbc.M605049200

28. Kawasaki N, Asada R, Saito A, Kanemoto S, Imaizumi K (2012) Obesity-induced endoplasmic reticulum stress causes chronic inflammation in adipose tissue. Sci Rep 2:799. doi:10.1038/srep00799

29. Kikuchi H, Almer G, Yamashita S, Guegan C, Nagai M, Xu Z, Sosunov AA, McKhann GM 2nd, Przedborski S (2006) Spinal cord endoplasmic reticulum stress associated with a microsomal accumulation of mutant superoxide dismutase-1 in an ALS model. Proc Natl Acad Sci 103(15):6025-6030. doi:10.1073/p nas.0509227103

30. Kristiansen M, Deriziotis P, Dimcheff DE, Jackson GS, Ovaa H, Naumann H, Clarke AR, van Leeuwen FWB, Menendez-Benito V, Dantuma NP, Portis JL, Collinge J, Tabrizi SJ (2007) Diseaseassociated prion protein oligomers inhibit the $26 \mathrm{~S}$ proteasome. Mol Cell 26(2):175-188. doi:10.1016/j.molcel.2007.04.001

31. Kulkarni B, Mohammed I, Hopkinson A, Dua HS (2011) Validation of endogenous control genes for gene expression studies on human ocular surface epithelium. PLoS ONE 6(8):e22301. doi:10.1371/journal.pone.0022301

32. Lee AH, Iwakoshi NN, Anderson KC, Glimcher LH (2003) Proteasome inhibitors disrupt the unfolded protein response in myeloma cells. Proc Natl Acad Sci 100(17):9946-9951. doi:10.1073/ pnas. 1334037100

33. Lee YB, Chen HJ, Peres JN, Gomez-Deza J, Attig J, Stalekar M, Troakes C, Nishimura AL, Scotter EL, Vance C, Adachi Y, Sardone V, Miller JW, Smith BN, Gallo JM, Ule J, Hirth F, Rogelj B, Houart C, Shaw CE (2013) Hexanucleotide repeats in ALS/FTD form length-dependent RNA foci, sequester RNA binding proteins, and are neurotoxic. Cell Rep 5(5):1178-1186. doi:10.1016/j.celrep.2013.10.049

34. Lin WL, Castanedes-Casey M, Dickson DW (2009) Transactivation response DNA-binding protein 43 microvasculopathy in frontotemporal degeneration and familial Lewy body disease. $\mathrm{J}$ Neuropathol Exp Neurol 68(11):1167-1176. doi:10.1097/NEN.0 b013e3181baacec

35. Lindersson E, Beedholm R, Hojrup P, Moos T, Gai W, Hendil KB, Jensen PH (2004) Proteasomal inhibition by alpha-synuclein filaments and oligomers. J Biol Chem 279(13):12924-12934. doi:10.1074/jbc.M306390200

36. Liu CL, Li X, Hu GL, Li RJ, He YY, Zhong W, Li S, He KL, Wang LL (2012) Salubrinal protects against tunicamycin and hypoxia induced cardiomyocyte apoptosis via the PERK-eIF2alpha signaling pathway. J Geriatr Cardiol 9(3):258-268. doi:10.37 24/SP.J.1263.2012.02292

37. Liu EY, Russ J, Wu K, Neal D, Suh E, McNally AG, Irwin DJ, Van Deerlin VM, Lee EB (2014) C9orf72 hypermethylation protects against repeat expansion-associated pathology in ALS/FTD. Acta Neuropathol. doi:10.1007/s00401-014-1286-y

38. Lo AC, Callaerts-Vegh $\mathrm{Z}$, Nunes AF, Rodrigues CM, D'Hooge R (2013) Tauroursodeoxycholic acid (TUDCA) 
supplementation prevents cognitive impairment and amyloid deposition in APP/PS1 mice. Neurobiol Dis 50:21-29. doi:10.1016/j.nbd.2012.09.003

39. Lomen-Hoerth C, Murphy J, Langmore S, Kramer JH, Olney RK, Miller B (2003) Are amyotrophic lateral sclerosis patients cognitively normal? Neurology 60(7):1094-1097

40. Mackenzie IR, Arzberger T, Kremmer E, Troost D, Lorenzl S, Mori K, Weng SM, Haass C, Kretzschmar HA, Edbauer D, Neumann M (2013) Dipeptide repeat protein pathology in C9ORF72 mutation cases: clinico-pathological correlations. Acta Neuropathol 126(6):859-879. doi:10.1007/s00401-013-1181-y

41. Majounie E, Renton AE, Mok K, Dopper EG, Waite A, Rollinson S, Chio A, Restagno G, Nicolaou N, Simon-Sanchez J, van Swieten JC, Abramzon Y, Johnson JO, Sendtner M, Pamphlett R, Orrell RW, Mead S, Sidle KC, Houlden H, Rohrer JD, Morrison KE, Pall H, Talbot K, Ansorge O, Hernandez DG, Arepalli S, Sabatelli M, Mora G, Corbo M, Giannini F, Calvo A, Englund E, Borghero G, Floris GL, Remes AM, Laaksovirta H, McCluskey L, Trojanowski JQ, Van Deerlin VM, Schellenberg GD, Nalls MA, Drory VE, Lu CS, Yeh TH, Ishiura H, Takahashi Y, Tsuji S, Le Ber I, Brice A, Drepper C, Williams N, Kirby J, Shaw P, Hardy J, Tienari PJ, Heutink P, Morris HR, Pickering-Brown S, Traynor BJ (2012) Frequency of the C9orf72 hexanucleotide repeat expansion in patients with amyotrophic lateral sclerosis and frontotemporal dementia: a cross-sectional study. Lancet Neurol 11(4):323-330. doi:10.1016/S1474-4422(12)70043-1

42. Marciniak SJ, Yun CY, Oyadomari S, Novoa I, Zhang Y, Jungreis R, Nagata K, Harding HP, Ron D (2004) CHOP induces death by promoting protein synthesis and oxidation in the stressed endoplasmic reticulum. Genes Dev 18(24):3066-3077. doi:10.1101/ gad. 1250704

43. Mori K, Arzberger T, Grasser FA, Gijselinck I, May S, Rentzsch K, Weng SM, Schludi MH, van der Zee J, Cruts M, Van Broeckhoven C, Kremmer E, Kretzschmar HA, Haass C, Edbauer D (2013) Bidirectional transcripts of the expanded C9orf72 hexanucleotide repeat are translated into aggregating dipeptide repeat proteins. Acta Neuropathol 126(6):881-893. doi:10.1007/ s00401-013-1189-3

44. Mori K, Weng SM, Arzberger T, May S, Rentzsch K, Kremmer E, Schmid B, Kretzschmar HA, Cruts M, Van Broeckhoven C, Haass C, Edbauer D (2013) The C9orf72 GGGGCC repeat is translated into aggregating dipeptide-repeat proteins in FTLD/ALS. Science 339(6125):1335-1338. doi:10.1126/science.1232927

45. Moumen A, Virard I, Raoul C (2011) Accumulation of wildtype and ALS-linked mutated VAPB impairs activity of the proteasome. PLoS ONE 6(10):e26066. doi:10.1371/ journal.pone. 0026066

46. Neumann M, Kwong LK, Truax AC, Vanmassenhove B, Kretzschmar HA, Van Deerlin VM, Clark CM, Grossman M, Miller BL, Trojanowski JQ, Lee VM (2007) TDP-43-positive white matter pathology in frontotemporal lobar degeneration with ubiquitin-positive inclusions. J Neuropathol Exp Neurol 66(3):177-183. doi:10.1097/01.jnen.0000248554.45456.58

47. Nishitoh H, Matsuzawa A, Tobiume K, Saegusa K, Takeda K, Inoue K, Hori S, Kakizuka A, Ichijo H (2002) ASK1 is essential for endoplasmic reticulum stress-induced neuronal cell death triggered by expanded polyglutamine repeats. Genes Dev 16(11):1345-1355. doi:10.1101/Gad.992302

48. Nishitoh H, Kadowaki H, Nagai A, Maruyama T, Yokota T, Fukutomi H, Noguchi T, Matsuzawa A, Takeda K, Ichijo H (2008) ALS-linked mutant SOD1 induces ER stress- and ASK1dependent motor neuron death by targeting Derlin-1. Genes Dev 22(11):1451-1464. doi:10.1101/gad.1640108

49. Novoa I, Zeng H, Harding HP, Ron D (2001) Feedback inhibition of the unfolded protein response by GADD34-mediated dephosphorylation of eIF2alpha. J Cell Biol 153(5):1011-1022
50. Obeng EA, Carlson LM, Gutman DM, Harrington WJ Jr, Lee KP, Boise LH (2006) Proteasome inhibitors induce a terminal unfolded protein response in multiple myeloma cells. Blood 107(12):4907-4916. doi:10.1182/blood-2005-08-3531

51. Oyadomari S, Mori M (2004) Roles of CHOP/GADD153 in endoplasmic reticulum stress. Cell Death Differ 11(4):381-389. doi:10.1038/sj.cdd.4401373

52. Ozcan U, Yilmaz E, Ozcan L, Furuhashi M, Vaillancourt E, Smith RO, Gorgun CZ, Hotamisligil GS (2006) Chemical chaperones reduce ER stress and restore glucose homeostasis in a mouse model of type 2 diabetes. Science 313(5790):1137-1140. doi:10.1126/science.1128294

53. Park HS, Jun do Y, Han CR, Woo HJ, Kim YH (2011) Proteasome inhibitor MG132-induced apoptosis via ER stress-mediated apoptotic pathway and its potentiation by protein tyrosine kinase p56lck in human Jurkat T cells. Biochem Pharmacol 82(9):1110 1125. doi:10.1016/j.bcp.2011.07.085

54. Phukan J, Pender NP, Hardiman O (2007) Cognitive impairment in amyotrophic lateral sclerosis. Lancet Neurol 6(11):994-1003. doi:10.1016/S1474-4422(07)70265-X

55. Prell T, Lautenschlager J, Witte OW, Carri MT, Grosskreutz J (2012) The unfolded protein response in models of human mutant G93A amyotrophic lateral sclerosis. Eur J Neurosci 35(5):652660. doi:10.1111/j.1460-9568.2012.08008.x

56. Proudfoot M, Gutowski NJ, Edbauer D, Hilton DA, Stephens M, Rankin J, Mackenzie IR (2014) Early dipeptide repeat pathology in a frontotemporal dementia kindred with C9ORF72 mutation and intellectual disability. Acta Neuropathol 127(3):451-458. doi:10.1007/s00401-014-1245-7

57. Reddy K, Zamiri B, Stanley SY, Macgregor RB Jr, Pearson CE (2013) The disease-associated $\mathrm{r}(\mathrm{GGGGCC}) \mathrm{n}$ repeat from the C9orf72 gene forms tract length-dependent uni- and multimolecular RNA G-quadruplex structures. J Biol Chem 288(14):98609866. doi:10.1074/jbc.C113.452532

58. Renton AE, Majounie E, Waite A, Simon-Sanchez J, Rollinson S, Gibbs JR, Schymick JC, Laaksovirta H, van Swieten JC, Myllykangas L, Kalimo H, Paetau A, Abramzon Y, Remes AM, Kaganovich A, Scholz SW, Duckworth J, Ding J, Harmer DW, Hernandez DG, Johnson JO, Mok K, Ryten M, Trabzuni D, Guerreiro RJ, Orrell RW, Neal J, Murray A, Pearson J, Jansen IE, Sondervan D, Seelaar H, Blake D, Young K, Halliwell N, Callister JB, Toulson G, Richardson A, Gerhard A, Snowden J, Mann D, Neary D, Nalls MA, Peuralinna T, Jansson L, Isoviita VM, Kaivorinne AL, Holtta-Vuori M, Ikonen E, Sulkava R, Bena$\operatorname{tar}$ M, Wuu J, Chio A, Restagno G, Borghero G, Sabatelli M, Heckerman D, Rogaeva E, Zinman L, Rothstein JD, Sendtner M, Drepper C, Eichler EE, Alkan C, Abdullaev Z, Pack SD, Dutra A, Pak E, Hardy J, Singleton A, Williams NM, Heutink P, PickeringBrown S, Morris HR, Tienari PJ, Traynor BJ (2011) A hexanucleotide repeat expansion in C9ORF72 is the cause of chromosome 9p21-linked ALS-FTD. Neuron 72(2):257-268. doi:10.1016/j. neuron.2011.09.010

59. Sasaki S (2010) Endoplasmic reticulum stress in motor neurons of the spinal cord in sporadic amyotrophic lateral sclerosis. J Neuropathol Exp Neurol 69(4):346-355. doi:10.1097/NEN.0b01 3e3181d44992

60. Saxena S, Cabuy E, Caroni P (2009) A role for motoneuron subtype-selective ER stress in disease manifestations of FALS mice. Nat Neurosci 12(5):627-636. doi:10.1038/nn.2297

61. Stankowski JN, Zeiger SL, Cohen EL, DeFranco DB, Cai J, McLaughlin B (2011) C-terminus of heat shock cognate 70 interacting protein increases following stroke and impairs survival against acute oxidative stress. Antioxid Redox Signal 14(10):1787-1801. doi:10.1089/ars.2010.3300

62. Suzuki H, Kanekura K, Levine TP, Kohno K, Olkkonen VM, Aiso S, Matsuoka M (2009) ALS-linked P56S-VAPB, an 
aggregated loss-of-function mutant of VAPB, predisposes motor neurons to ER stress-related death by inducing aggregation of co-expressed wild-type VAPB. J Neurochem 108(4):973-985. doi:10.1111/j.0022-3042.2008.05857.x

63. Tabas I, Ron D (2011) Integrating the mechanisms of apoptosis induced by endoplasmic reticulum stress. Nat Cell Biol 13(3):184-190. doi:10.1038/ncb0311-184

64. Taylor JP (2014) Neurodegenerative diseases: G-quadruplex poses quadruple threat. Nature 507(7491):175-177. doi:10.1038/ nature 13067

65. Todd PK, Oh SY, Krans A, He F, Sellier C, Frazer M, Renoux AJ, Chen KC, Scaglione KM, Basrur V, Elenitoba-Johnson K, Vonsattel JP, Louis ED, Sutton MA, Taylor JP, Mills RE, Charlet-Berguerand N, Paulson HL (2013) CGG repeat-associated translation mediates neurodegeneration in fragile $\mathrm{X}$ tremor ataxia syndrome. Neuron 78(3):440-455. doi:10.1016/j.neuron.2013.03.026

66. Tsaytler P, Harding HP, Ron D, Bertolotti A (2011) Selective inhibition of a regulatory subunit of protein phosphatase 1 restores proteostasis. Science 332(6025):91-94. doi:10.1126/ science. 1201396

67. Urra H, Dufey E, Lisbona F, Rojas-Rivera D, Hetz C (2013) When ER stress reaches a dead end. Biochim Et Biophys Acta Mol Cell Res 1833(12):3507-3517. doi:10.1016/j.bbamcr.2013.07.024

68. Vaccaro A, Patten SA, Aggad D, Julien C, Maios C, Kabashi E, Drapeau P, Parker JA (2013) Pharmacological reduction of ER stress protects against TDP-43 neuronal toxicity in vivo. Neurobiol Dis 55:64-75. doi:10.1016/j.nbd.2013.03.015

69. Vijayalakshmi K, Alladi PA, Ghosh S, Prasanna VK, Sagar BC, Nalini A, Sathyaprabha TN, Raju TR (2011) Evidence of endoplasmic reticular stress in the spinal motor neurons exposed to CSF from sporadic amyotrophic lateral sclerosis patients. Neurobiol Dis 41(3):695-705. doi:10.1016/j.nbd.2010.12.005

70. Walker AK, Soo KY, Sundaramoorthy V, Parakh S, Ma Y, Farg MA, Wallace RH, Crouch PJ, Turner BJ, Horne MK, Atkin JD (2013) ALS-associated TDP-43 induces endoplasmic reticulum stress, which drives cytoplasmic TDP-43 accumulation and stress granule formation. PLoS ONE 8(11):e81170. doi:10.1371/ journal.pone.0081170

71. Wang J, Wang CE, Orr A, Tydlacka S, Li SH, Li XJ (2008) Impaired ubiquitin-proteasome system activity in the synapses of
Huntington's disease mice. J Cell Biol 180(6):1177-1189. doi:10. 1083/jcb.200709080

72. Wei H, Kim SJ, Zhang Z, Tsai PC, Wisniewski KE, Mukherjee AB (2008) ER and oxidative stresses are common mediators of apoptosis in both neurodegenerative and non-neurodegenerative lysosomal storage disorders and are alleviated by chemical chaperones. Hum Mol Genet 17(4):469-477. doi:10.1093/hmg/ ddm324

73. Xi Z, Zinman L, Moreno D, Schymick J, Liang Y, Sato C, Zheng Y, Ghani M, Dib S, Keith J, Robertson J, Rogaeva E (2013) Hypermethylation of the $\mathrm{CpG}$ island near the G4C2 repeat in ALS with a C9orf72 expansion. Am J Hum Genet 92(6):981989. doi:10.1016/j.ajhg.2013.04.017

74. Xu C, Bailly-Maitre B, Reed JC (2005) Endoplasmic reticulum stress: cell life and death decisions. J Clin Investig 115(10):26562664. doi:10.1172/JCI26373

75. Zhang YJ, Xu YF, Dickey CA, Buratti E, Baralle F, Bailey R, Pickering-Brown S, Dickson D, Petrucelli L (2007) Progranulin mediates caspase-dependent cleavage of TAR DNA binding protein-43. J Neurosci 27(39):10530-10534. doi:10.1523/JNEURO SCI.3421-07.2007

76. Zhang YJ, Caulfield T, Xu YF, Gendron TF, Hubbard J, Stetler C, Sasaguri H, Whitelaw EC, Cai S, Lee WC, Petrucelli L (2013) The dual functions of the extreme N-terminus of TDP-43 in regulating its biological activity and inclusion formation. Hum Mol Genet 22(15):3112-3122. doi: $10.1093 / \mathrm{hmg} / \mathrm{ddt} 166$

77. Zu T, Gibbens B, Doty NS, Gomes-Pereira M, Huguet A, Stone MD, Margolis J, Peterson M, Markowski TW, Ingram MA, Nan Z, Forster C, Low WC, Schoser B, Somia NV, Clark HB, Schmechel S, Bitterman PB, Gourdon G, Swanson MS, Moseley M, Ranum LP (2011) Non-ATG-initiated translation directed by microsatellite expansions. Proc Natl Acad Sci 108(1):260-265. doi:10.1073/pnas.1013343108

78. Zu T, Liu Y, Banez-Coronel M, Reid T, Pletnikova O, Lewis J, Miller TM, Harms MB, Falchook AE, Subramony SH, Ostrow LW, Rothstein JD, Troncoso JC, Ranum LP (2013) RAN proteins and RNA foci from antisense transcripts in C9ORF72 ALS and frontotemporal dementia. Proc Natl Acad Sci 110(51):E4968-E4977. doi:10.1073/pnas.1315438110 